University of Massachusetts Amherst ScholarWorks@UMass Amherst

Adjunct Faculty Author Gallery

1993

\title{
Lexical development in bilingual infants and toddlers: Comparison to monolingual norms
}

Barbara Zurer Pearson

University of Miami, bpearson@research.umass.edu

Sylvia C. Fernandez

University of Miami

D.Kimbrough Oller

University of Miami, koller@memphis.edu

Follow this and additional works at: https://scholarworks.umass.edu/adjunct_sw

Part of the Applied Linguistics Commons, Bilingual, Multilingual, and Multicultural Education Commons, Educational Assessment, Evaluation, and Research Commons, First and Second Language Acquisition Commons, Psycholinguistics and Neurolinguistics Commons, and the Speech and Hearing Science Commons

Pearson, Barbara Zurer; Fernandez, Sylvia C.; and Oller, D.Kimbrough, "Lexical development in bilingual infants and toddlers: Comparison to monolingual norms" (1993). Language Learning. 7.

Retrieved from https://scholarworks.umass.edu/adjunct_sw/7

This Article is brought to you for free and open access by ScholarWorks@UMass Amherst. It has been accepted for inclusion in Adjunct Faculty Author Gallery by an authorized administrator of ScholarWorks@UMass Amherst. For more information, please contact scholarworks@library.umass.edu. 


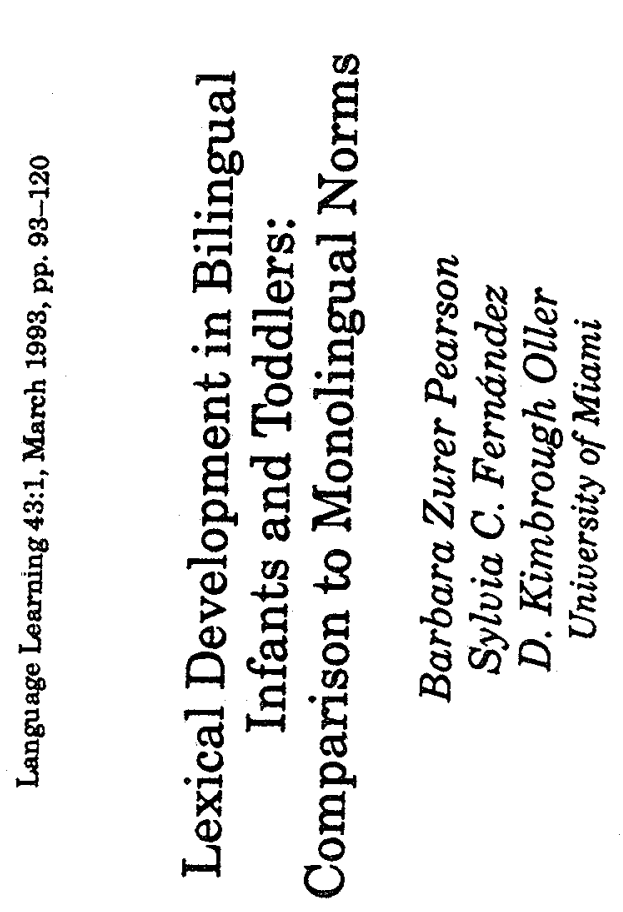

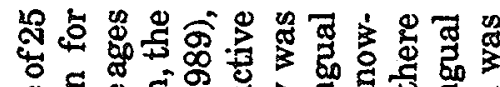

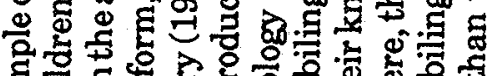

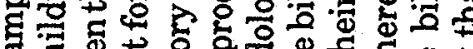
空 西

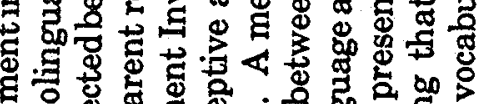

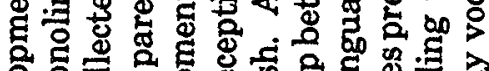

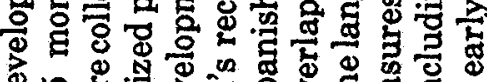

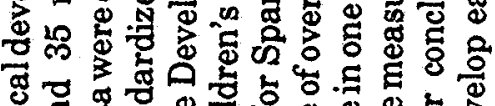

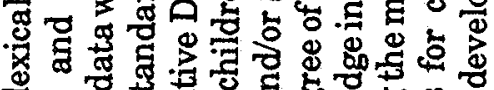

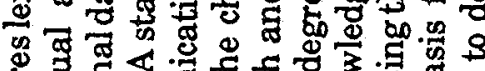

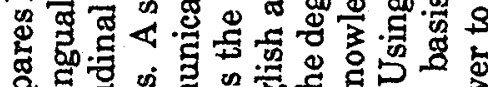

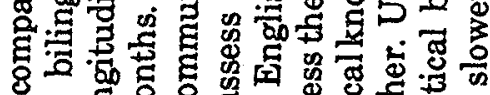
8 है

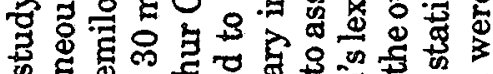

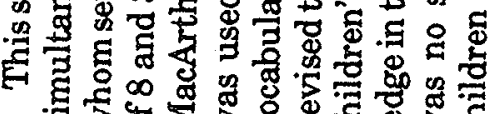

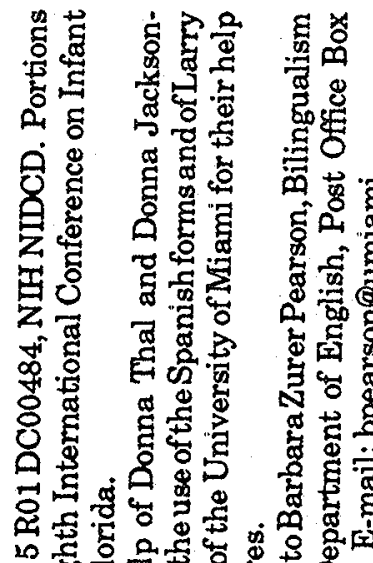

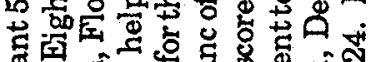

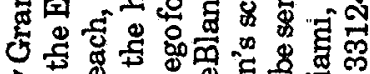

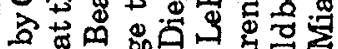

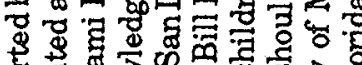

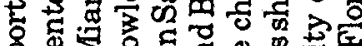
象它

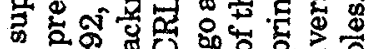

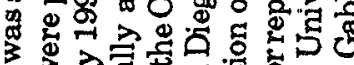
ᄃ ब $\$ \infty$ 每

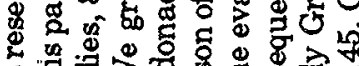

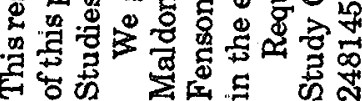




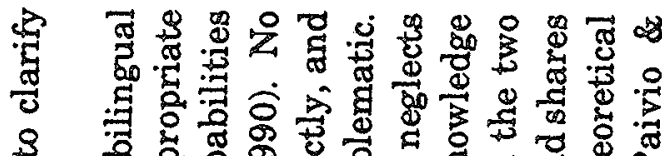

๘

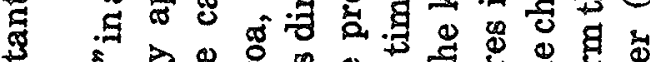

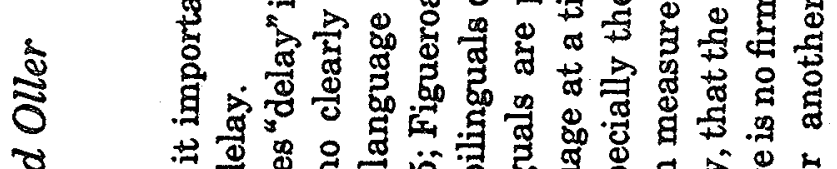

శ్రి

$\frac{1}{3}$

ఫิ

d

范

ชั่

R
خั ए 蛋

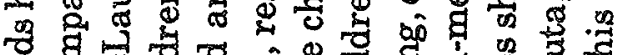
वृ ¿

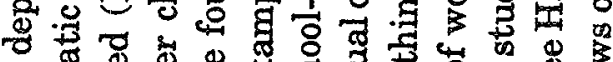

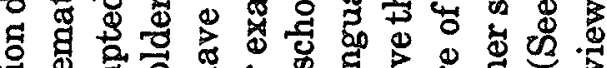

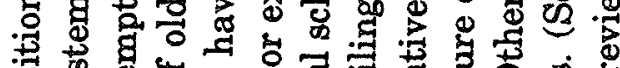

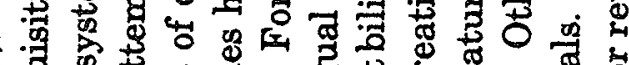
no

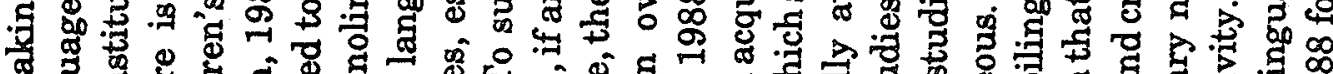

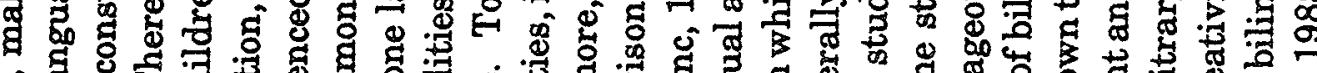

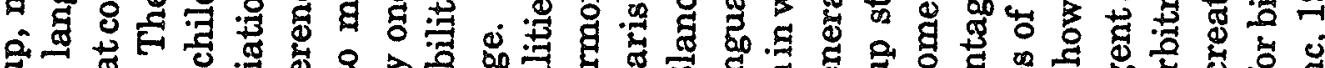

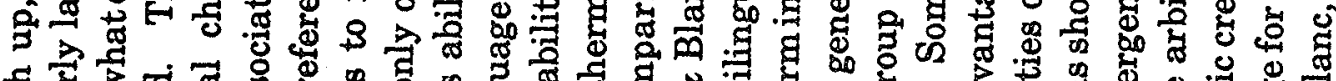

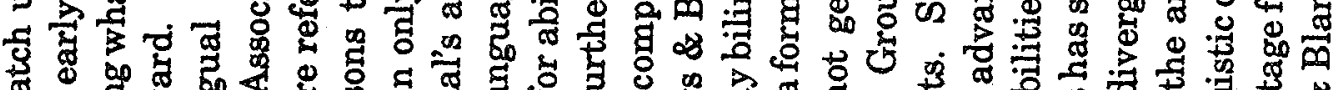
行

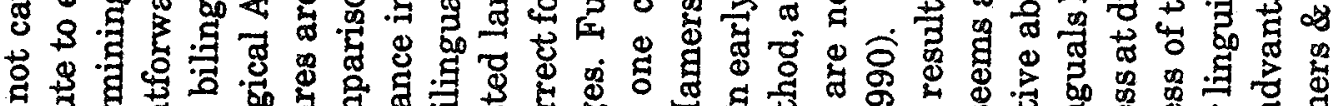

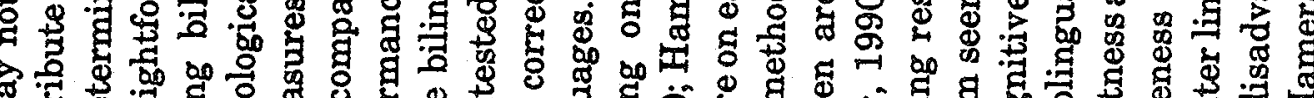

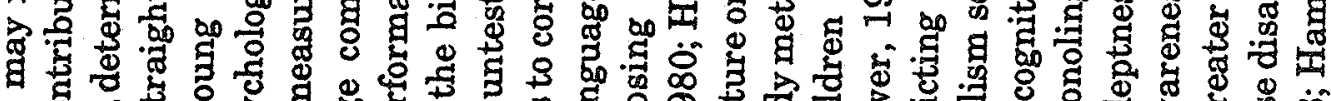

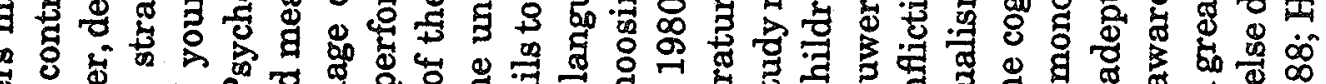

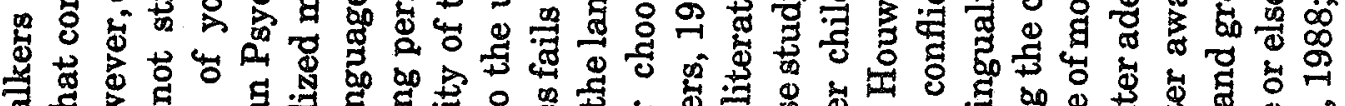

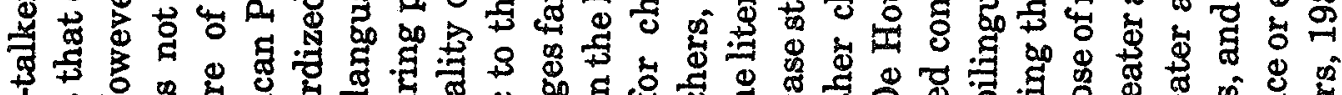

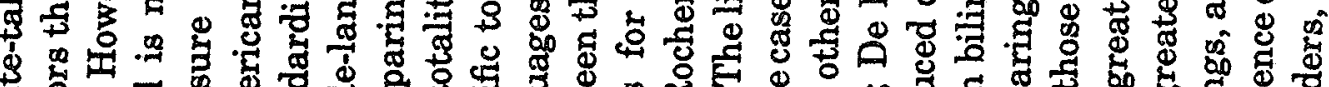

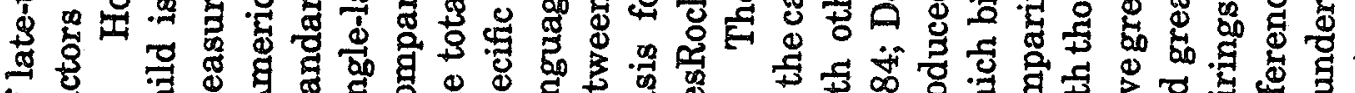

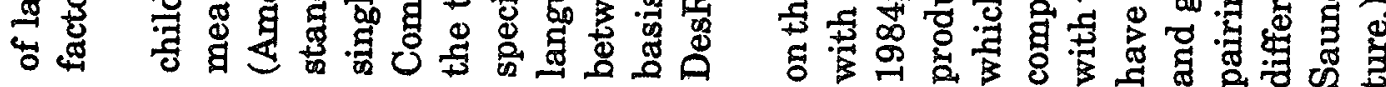

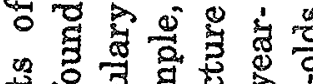

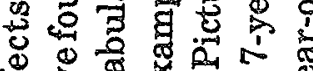
幽 氠边要 \%

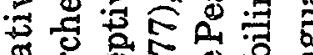
$\infty 0$ 녕 0 屯 क्षै

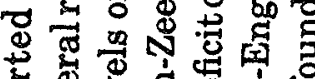
के

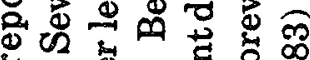
2. $\Rightarrow$ क

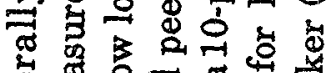

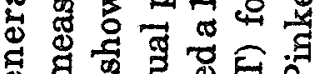

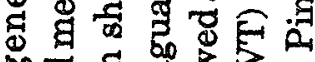

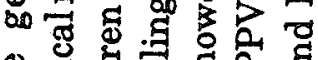

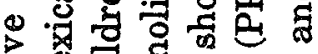

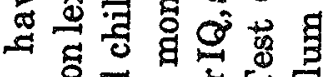
\& 중

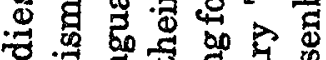
그 论

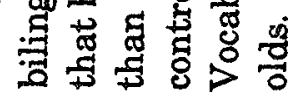

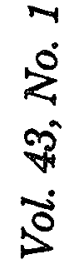

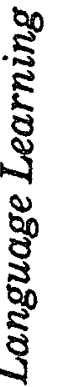

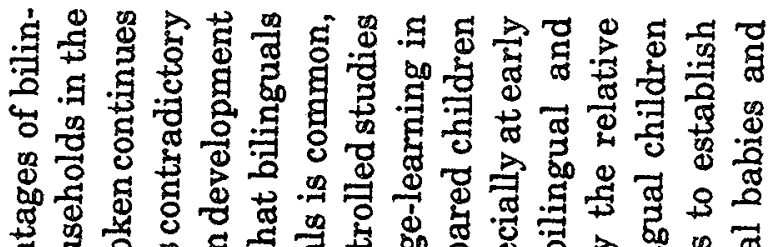

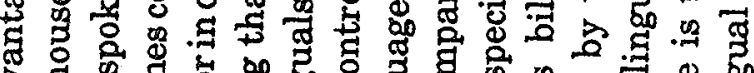

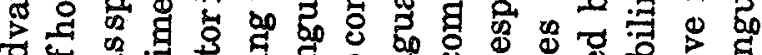

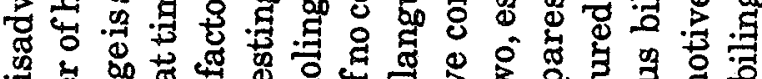

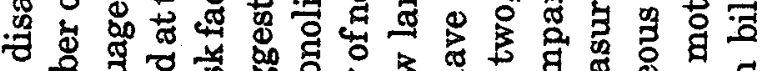

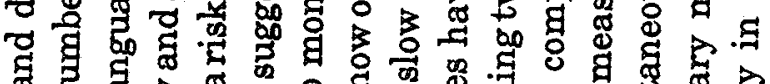

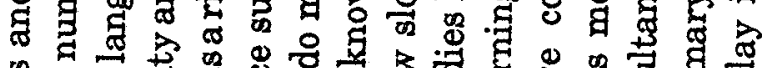

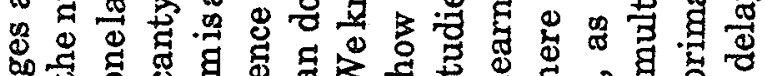

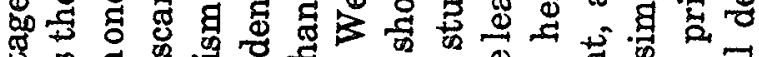
范

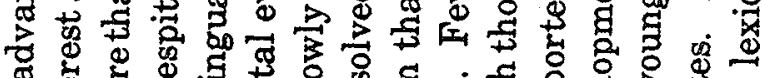
๙

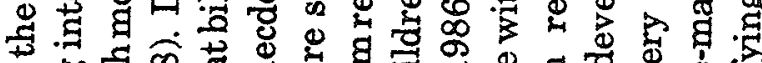
फ它 (. \&

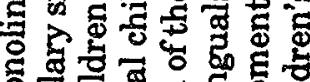

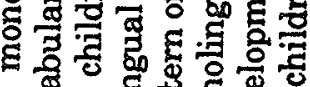

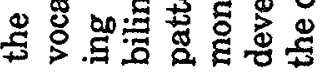

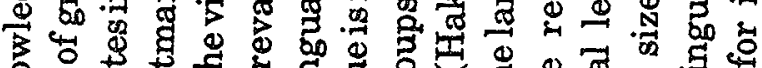

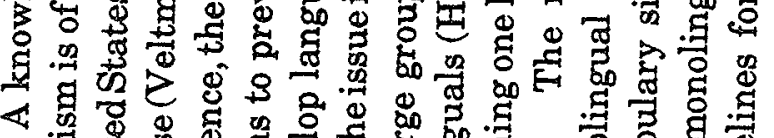

幽 จ ช \%

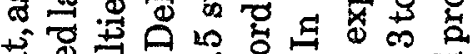

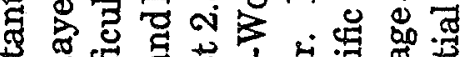

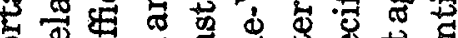

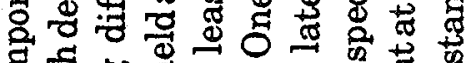
马्व

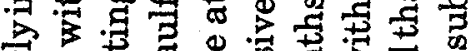

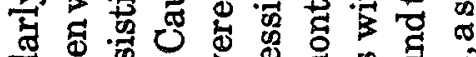

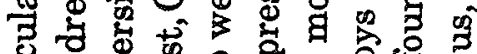

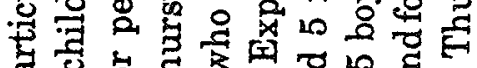

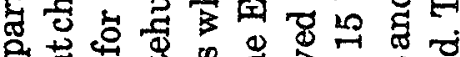

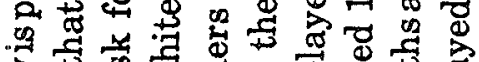

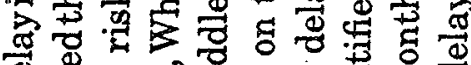
む

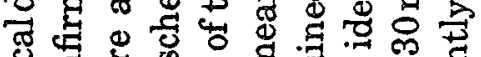
. Q

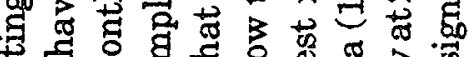

क . क्रु

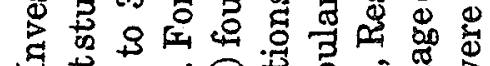

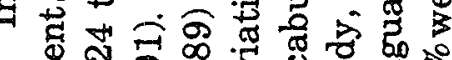
ब 년 


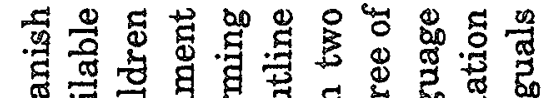

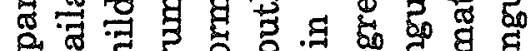

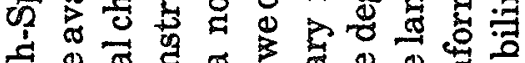
क ช०

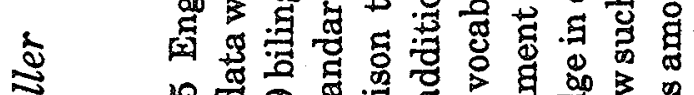

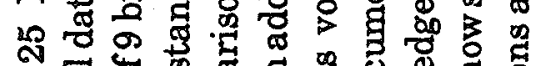

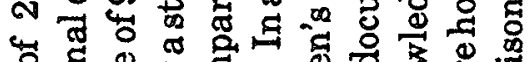

ญ

ఫू

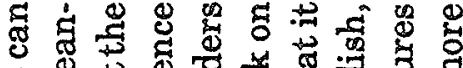
$\rightarrow$ \& \$ \& 8 \% मे व 2 ह

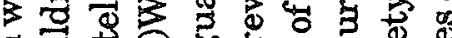

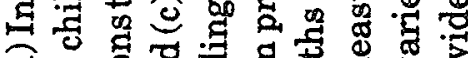

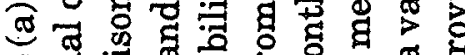
ه З

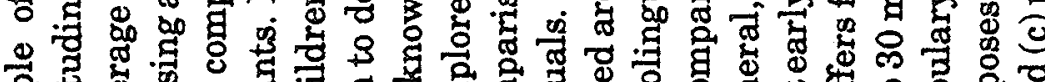

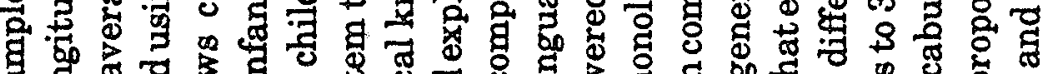

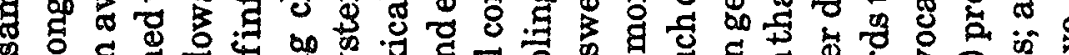
๙ .

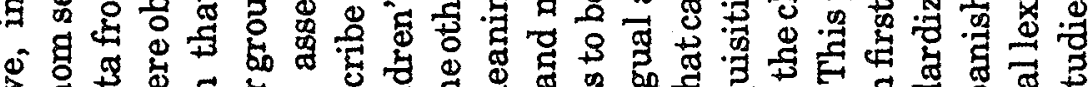

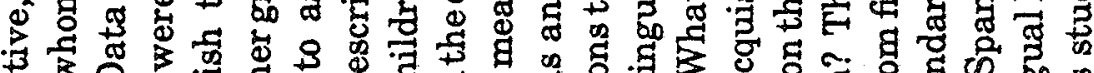

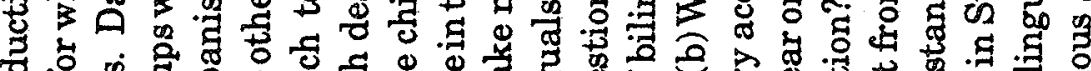
둔 i b. 起

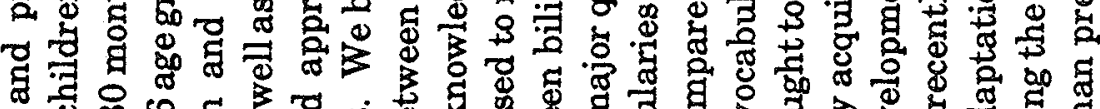
" त

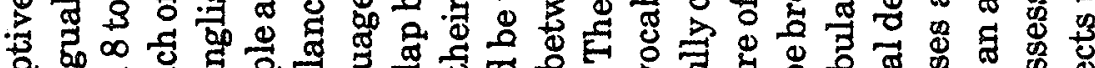

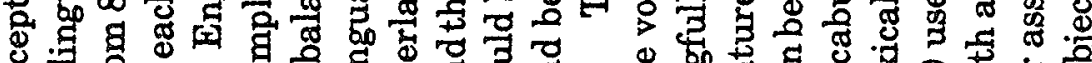

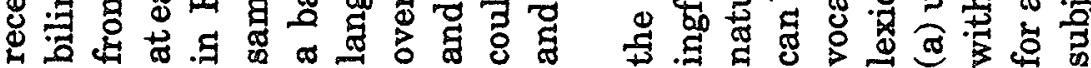

ఏ

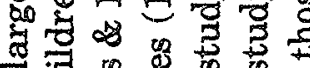

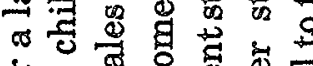
பै

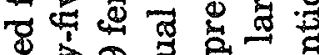

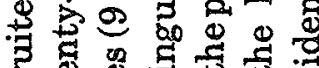

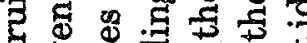

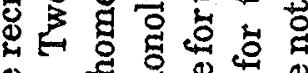
ष

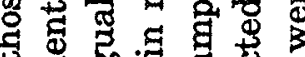

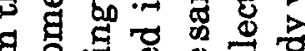

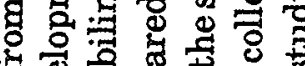

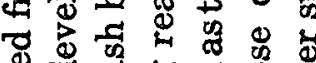

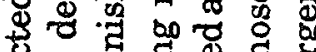

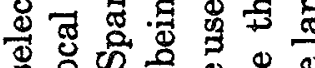

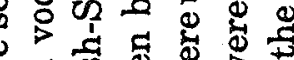

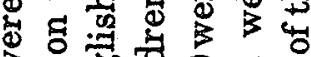
응 궁

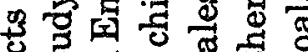
苏.

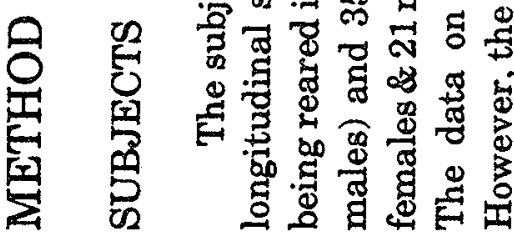

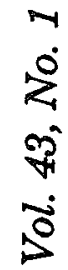

ב్ర

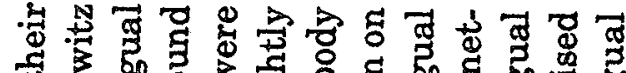

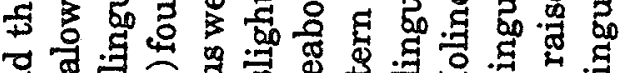

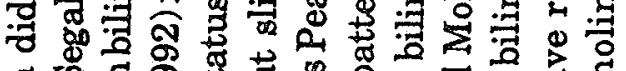

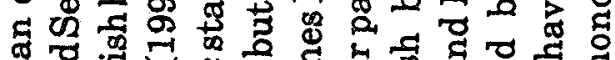

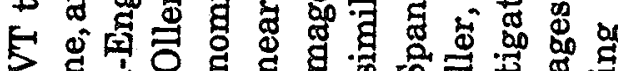
ह :

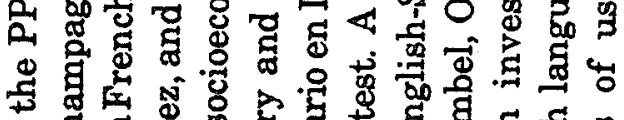

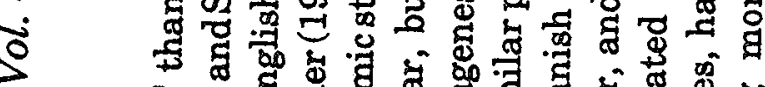

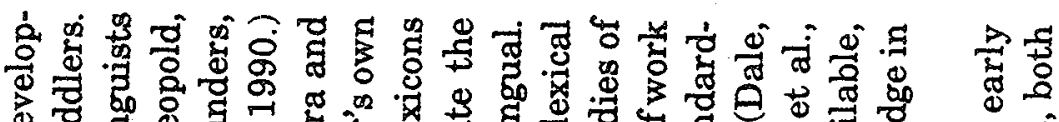

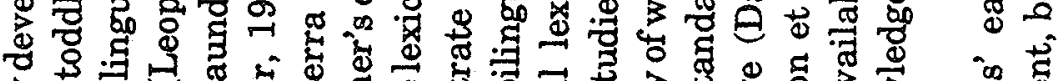

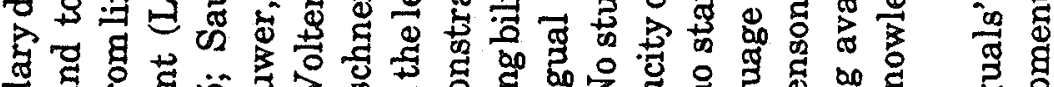

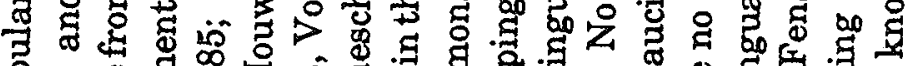

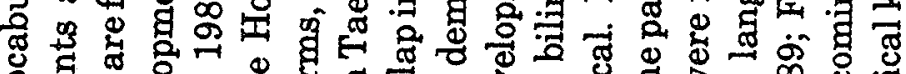

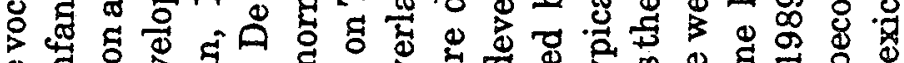

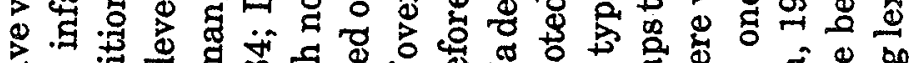

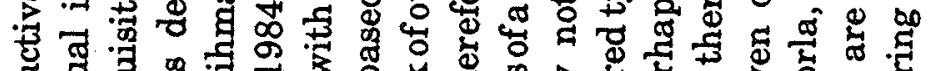

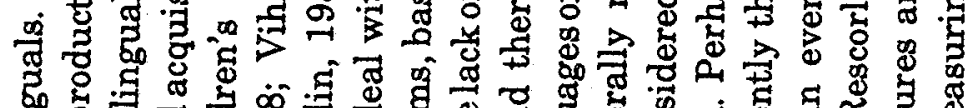

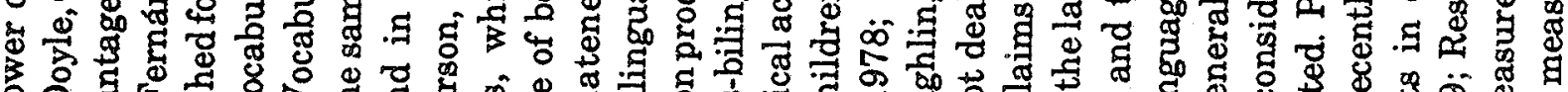

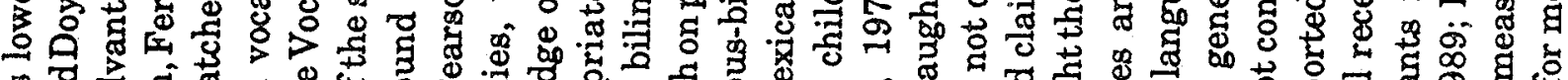

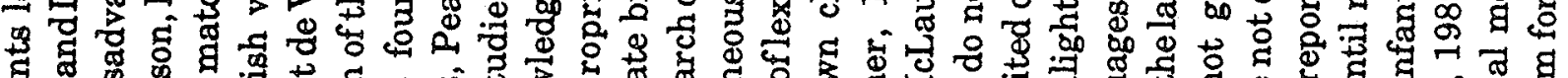

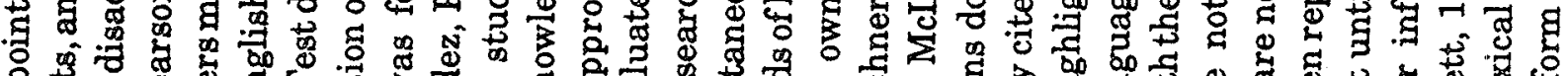

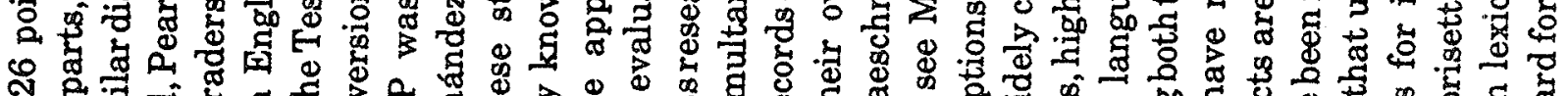
क क्ठ 屯 * క خ

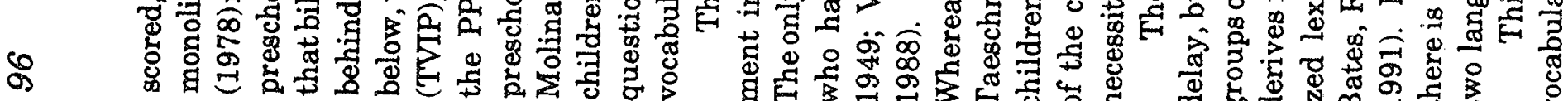




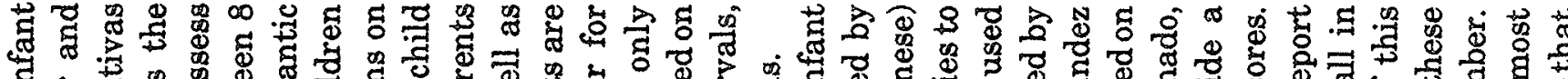

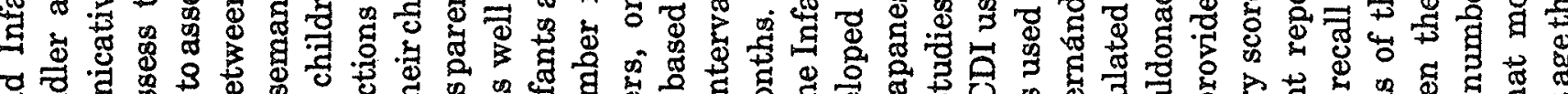

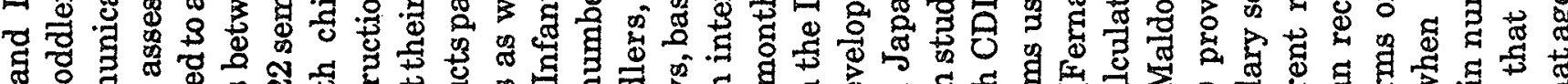
๘

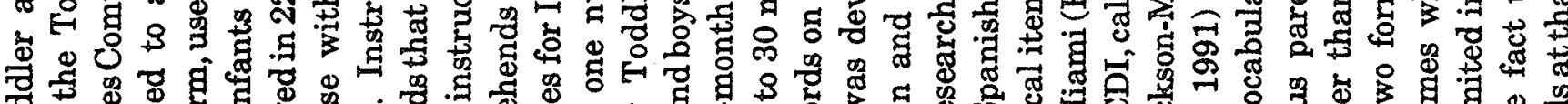

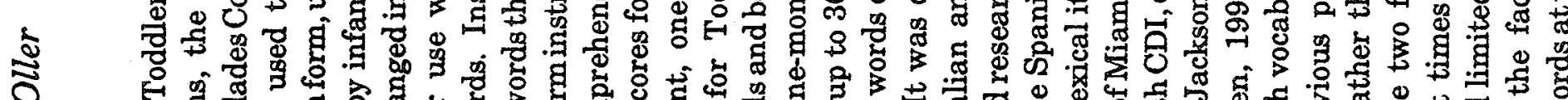

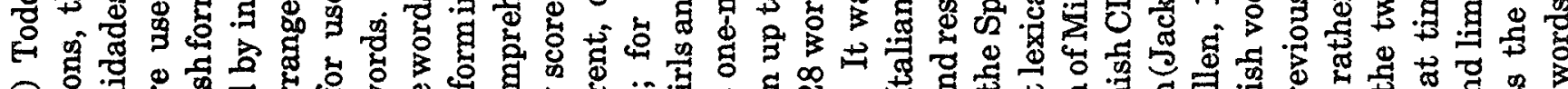

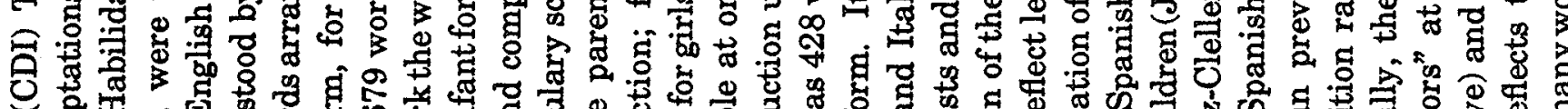

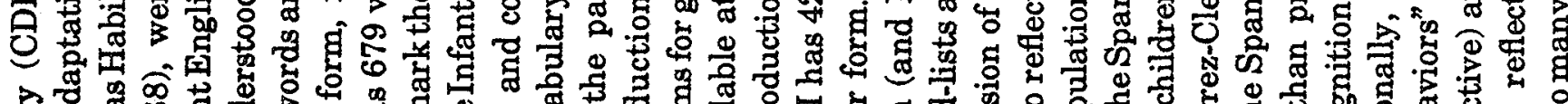

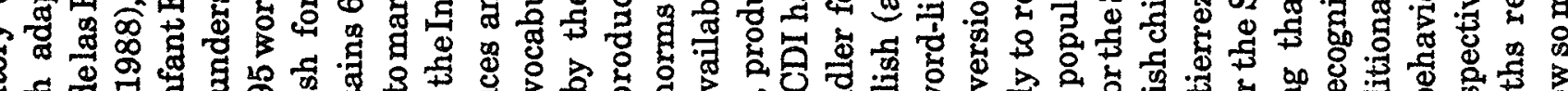

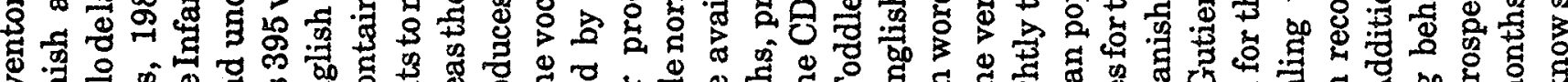

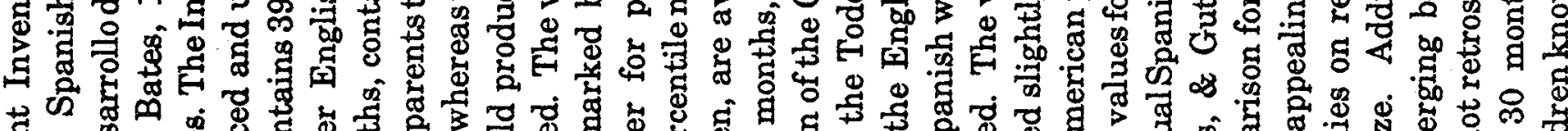

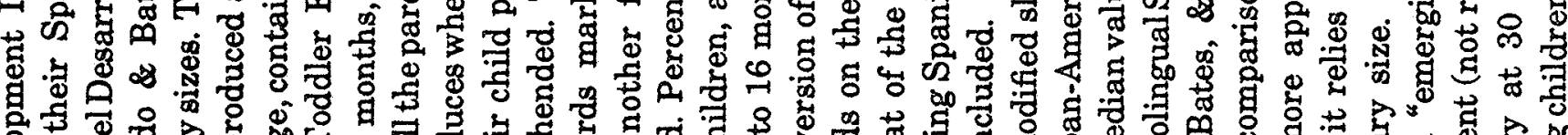

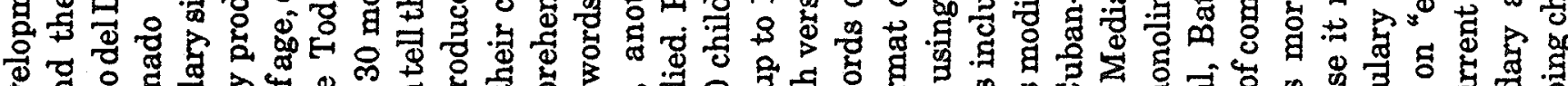

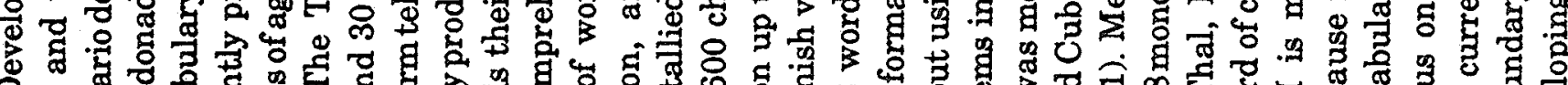

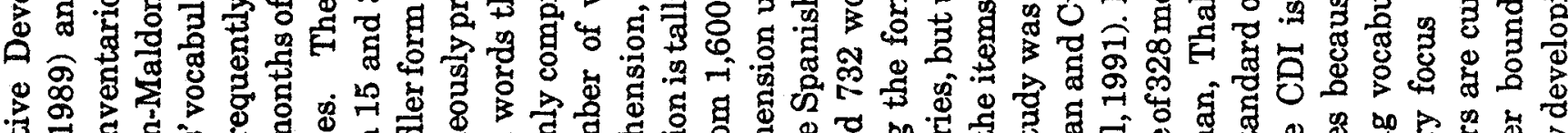

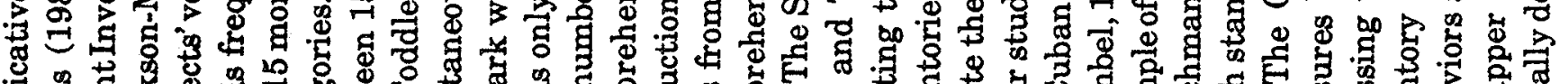

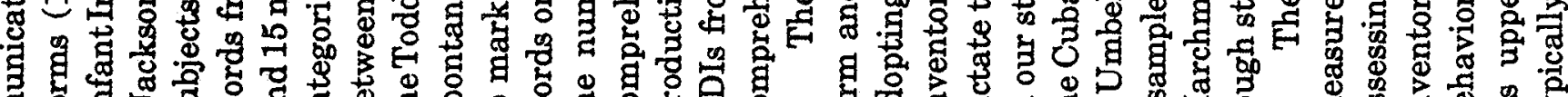

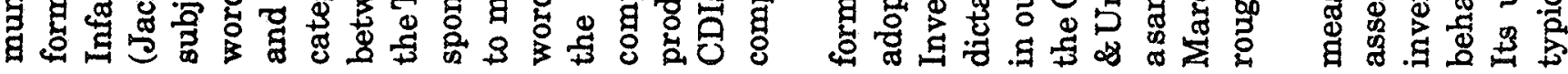

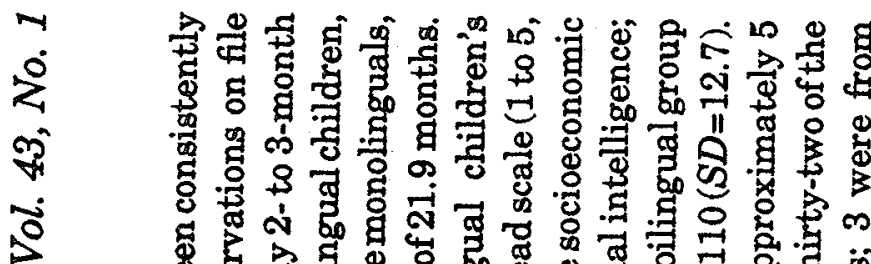

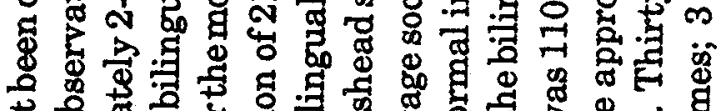

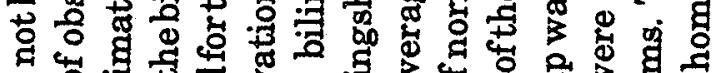

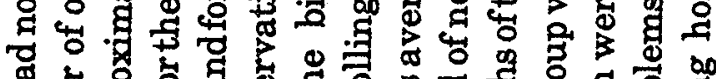

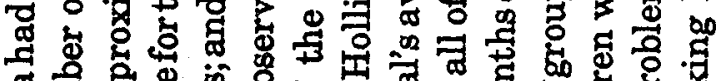

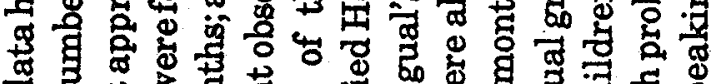

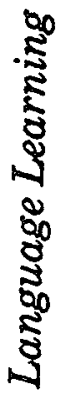

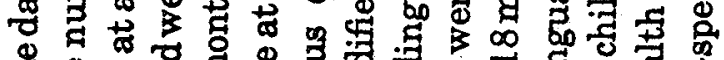

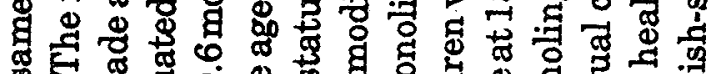

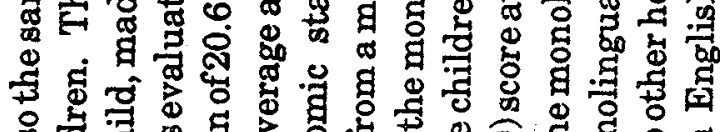

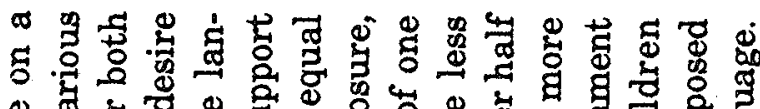

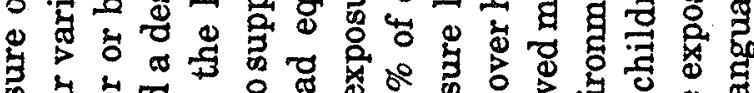

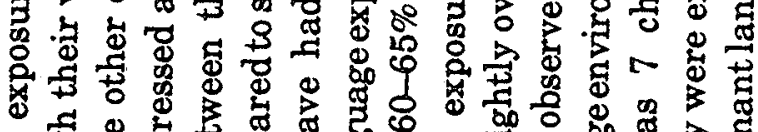

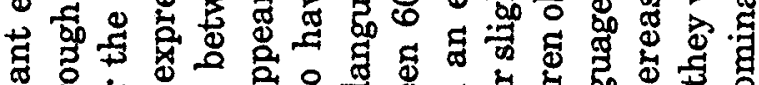

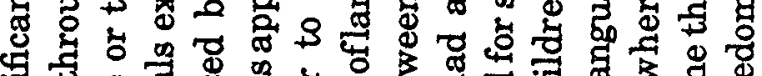

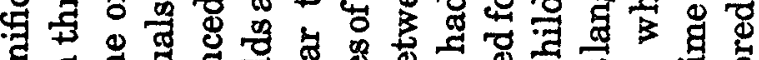

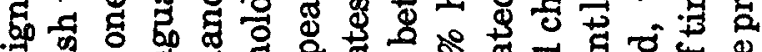

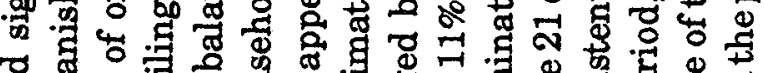

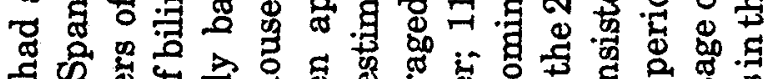

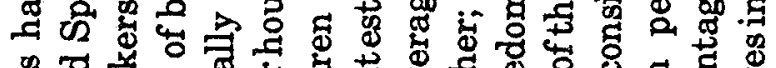

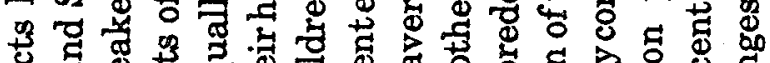

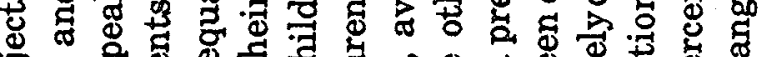

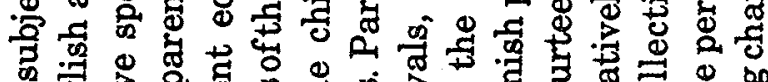

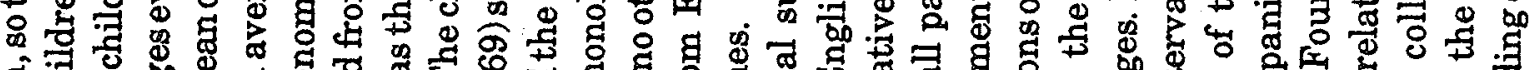
今ं

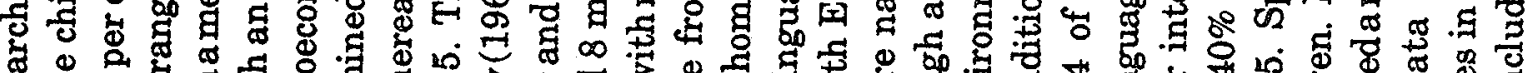

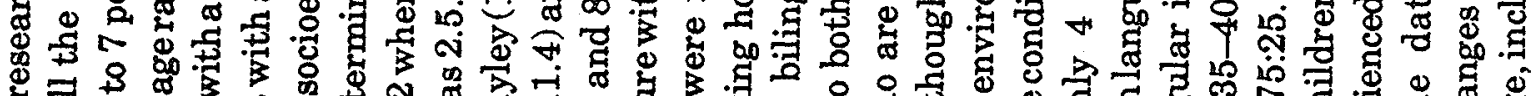

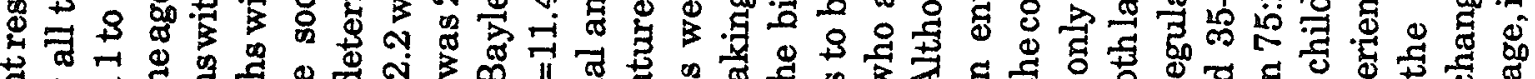

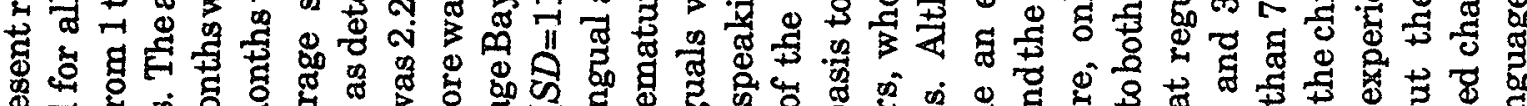

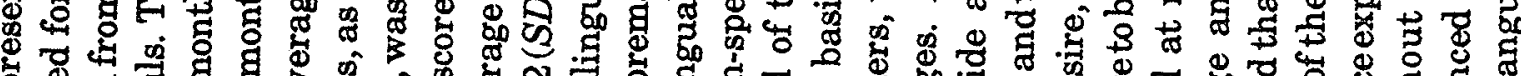

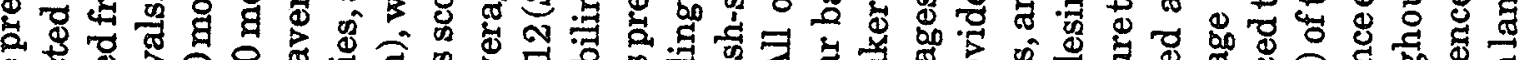

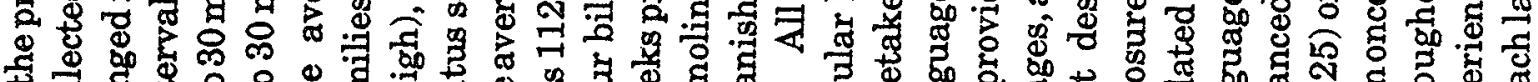

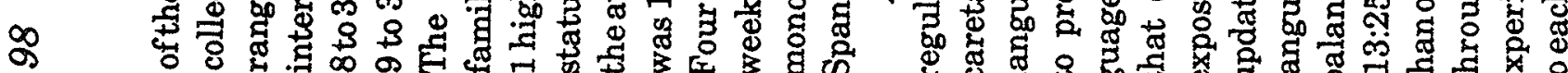




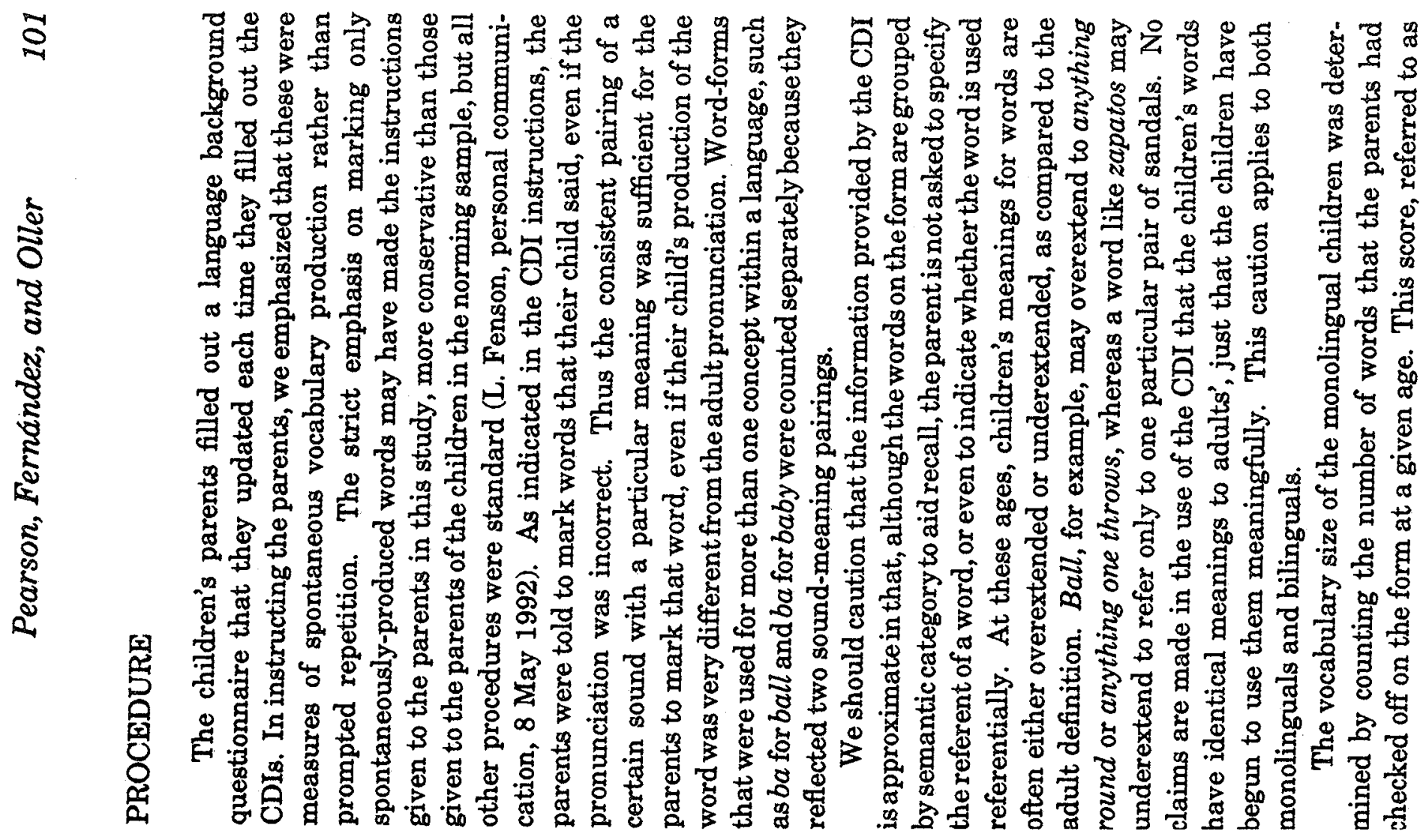

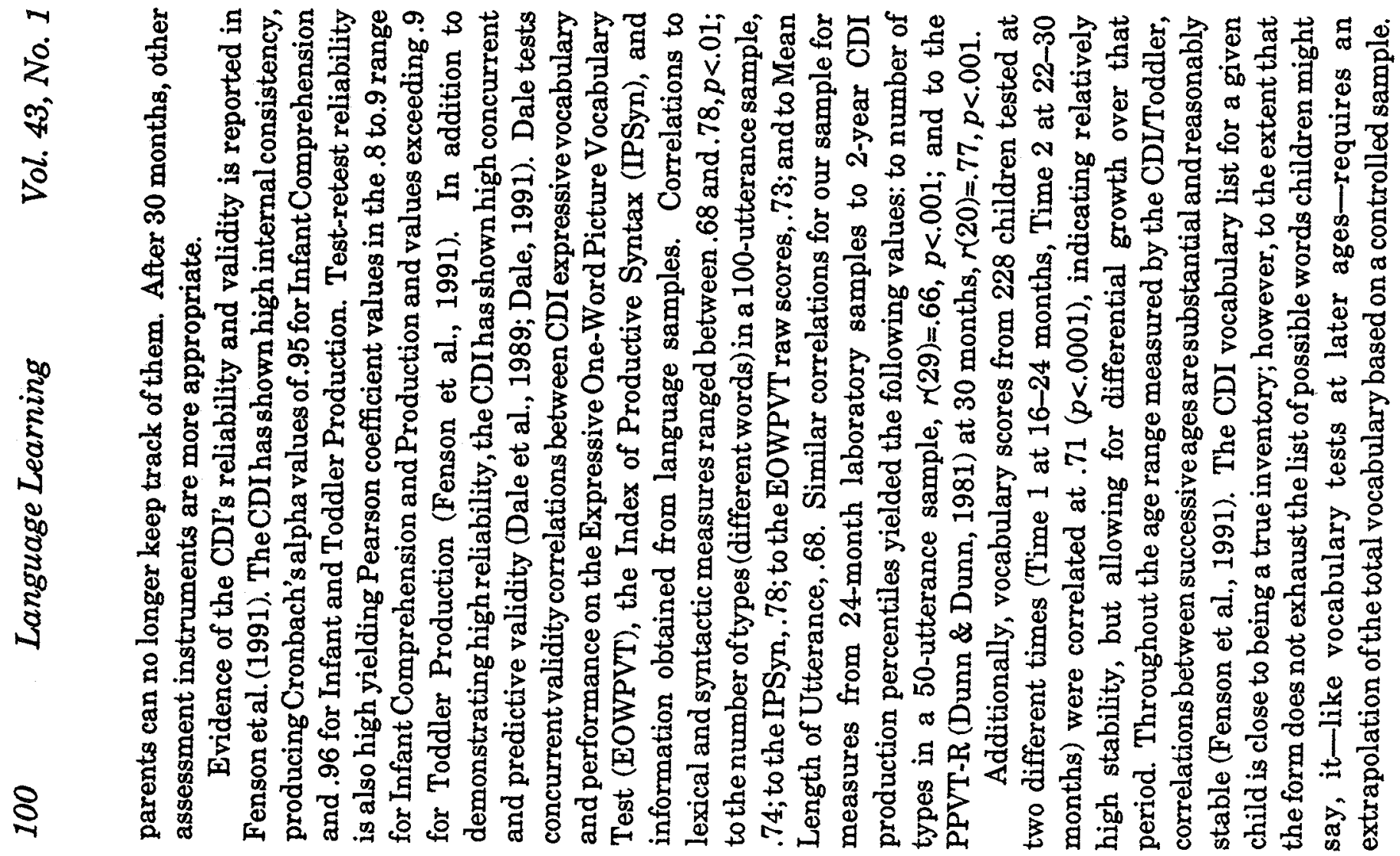




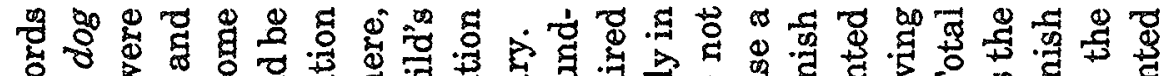

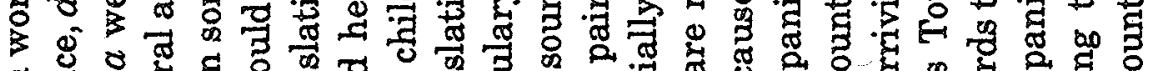
뎡

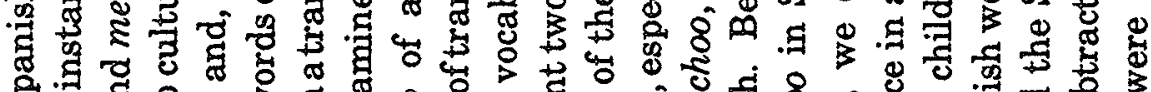

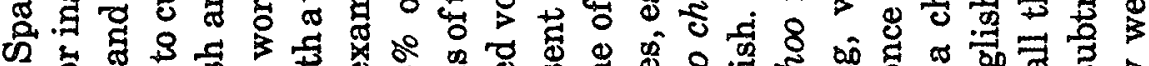

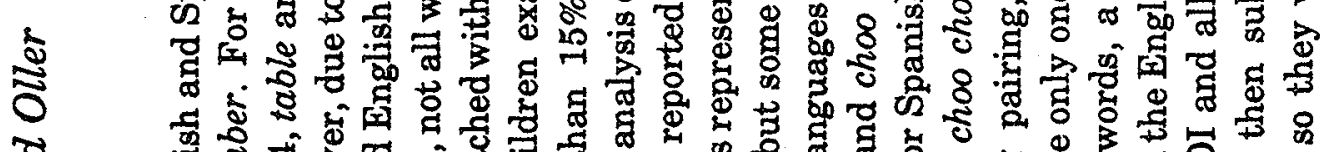

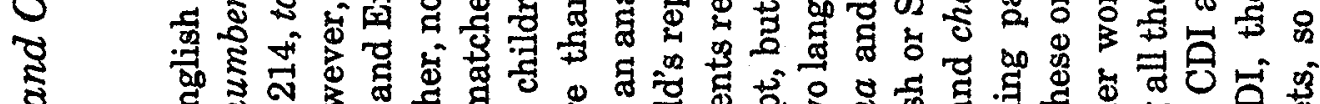

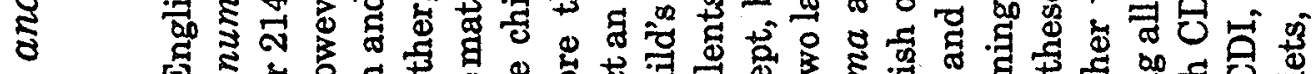

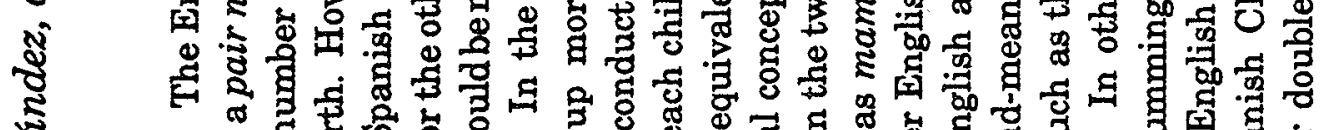

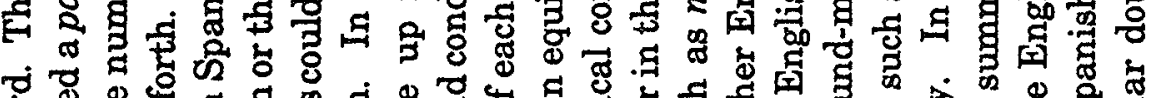

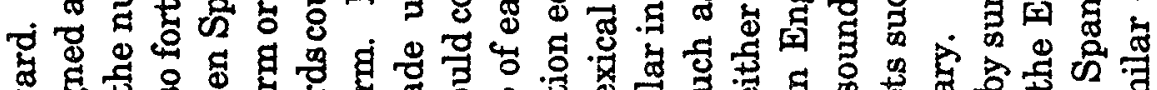

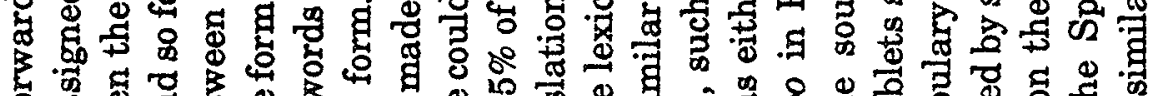
5 S

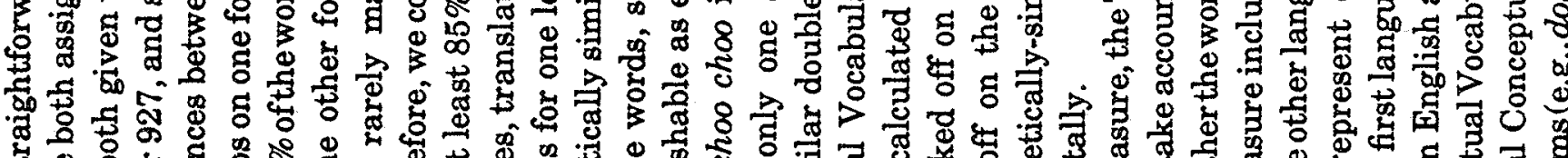
范。 \% 0 过 0

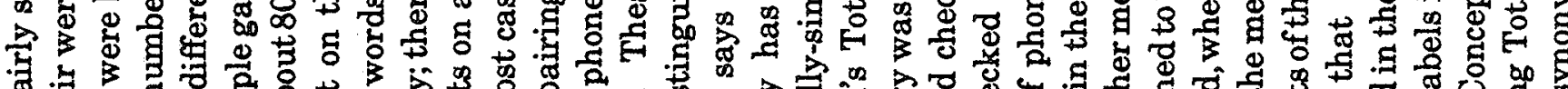

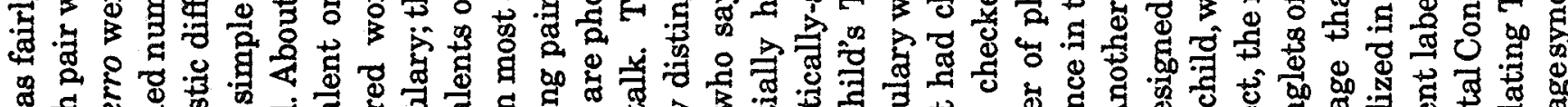

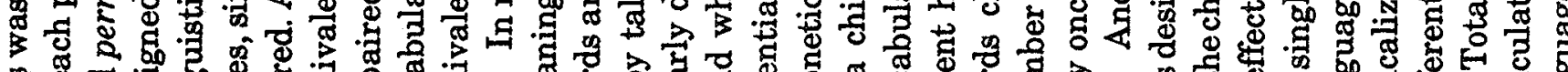
.

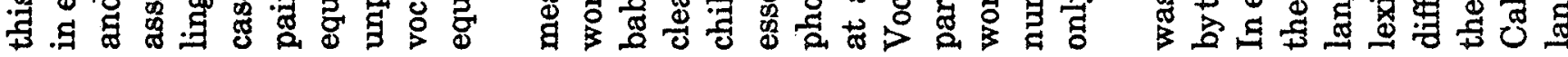

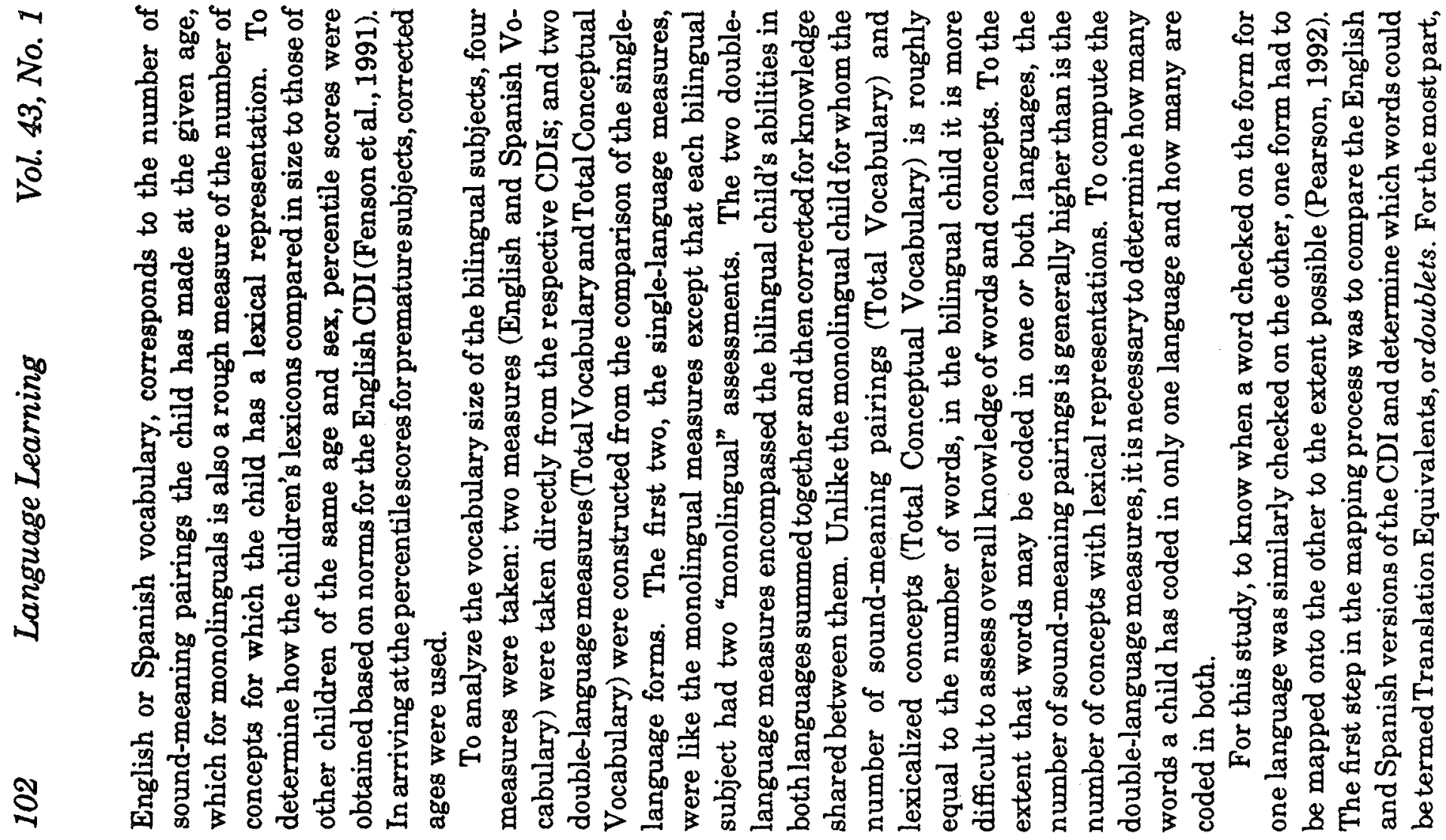




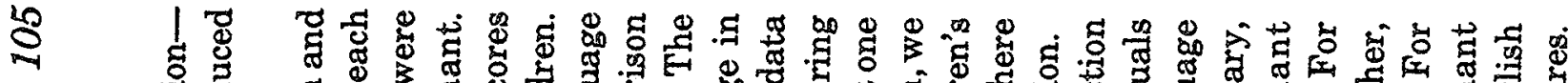

旁 要.

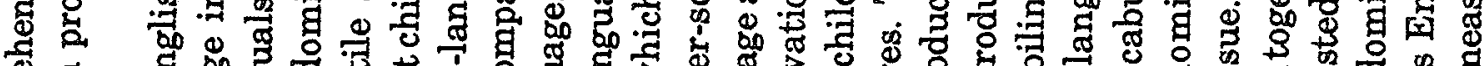

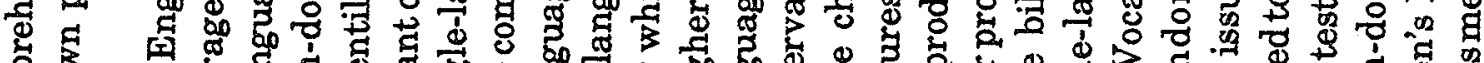

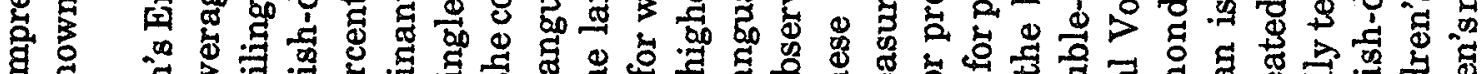

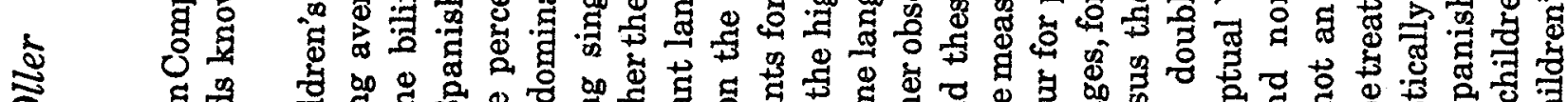

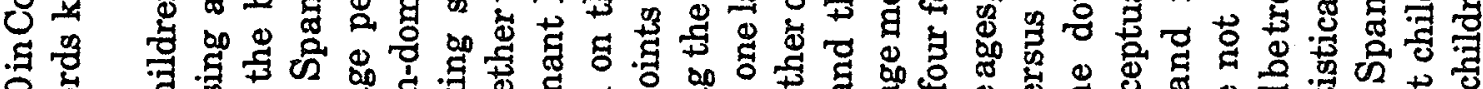

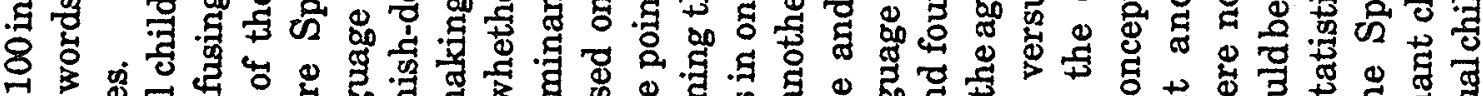

కి

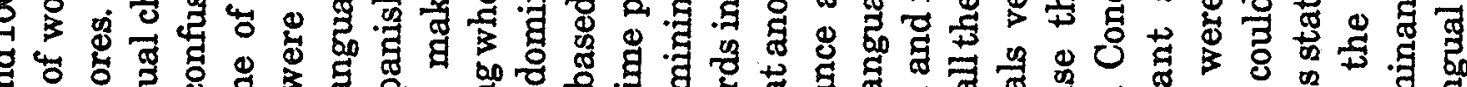
施

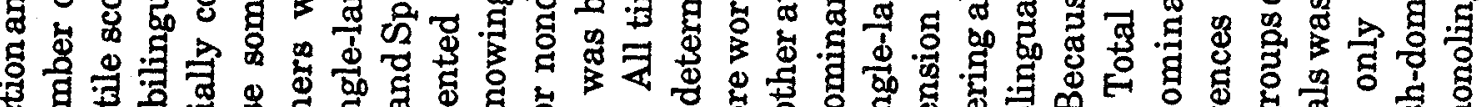

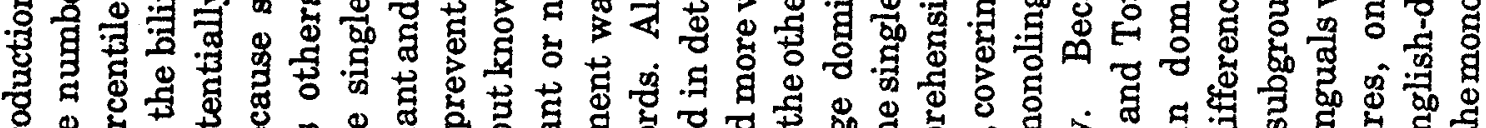

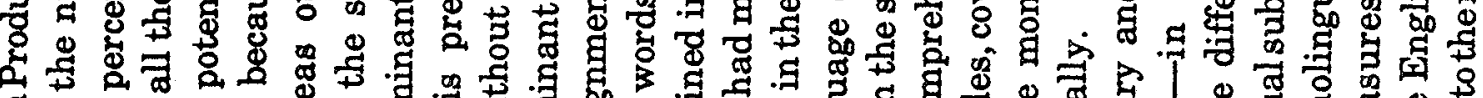
.9.9.5 吉.9

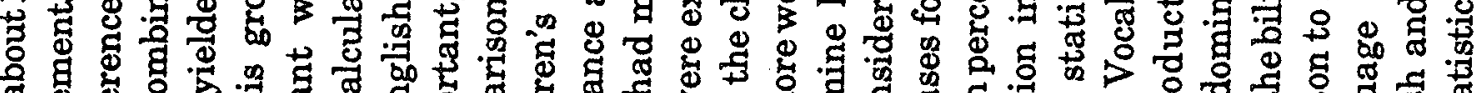

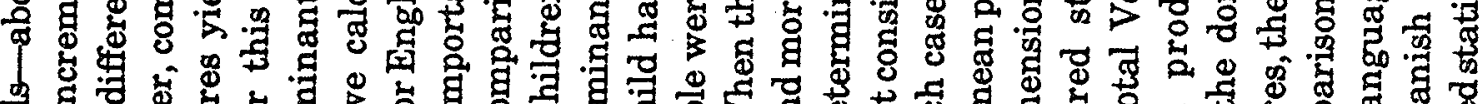
马.

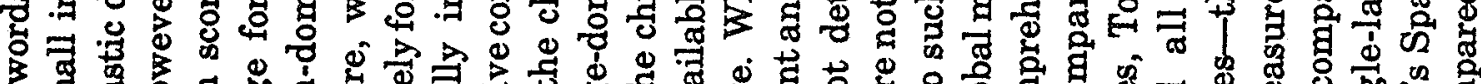

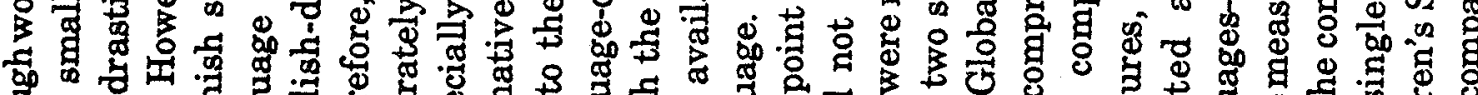

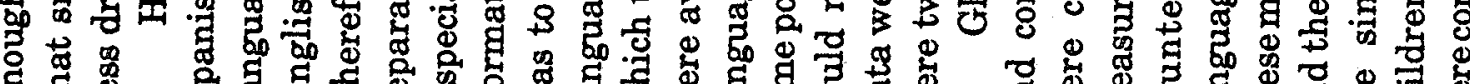

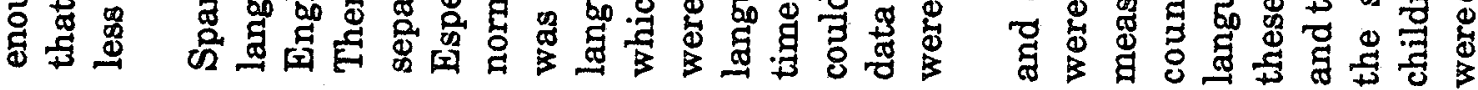

$\frac{1}{2}$

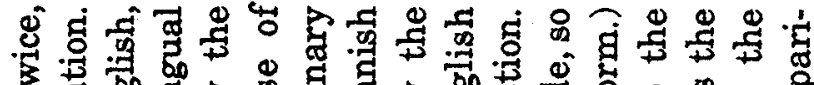

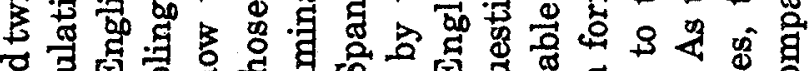

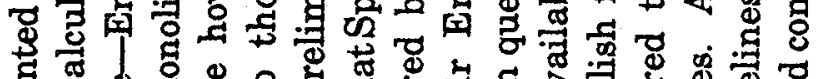
帘

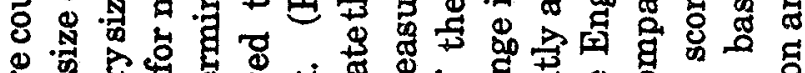

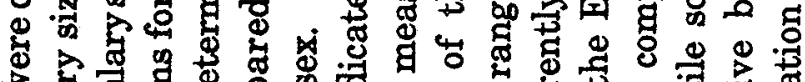

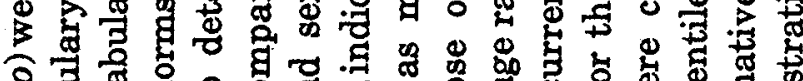

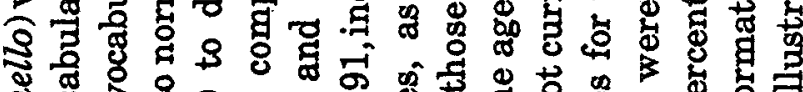
进蛋

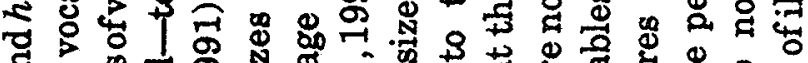

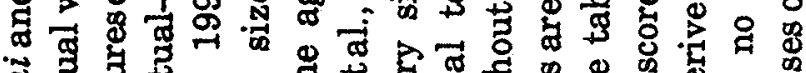

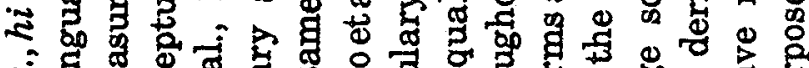
क.

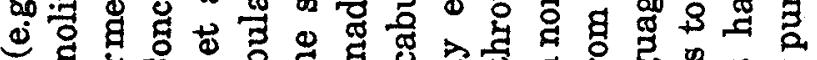

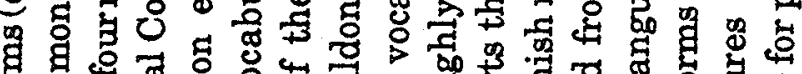

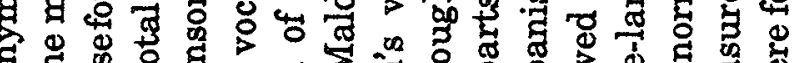

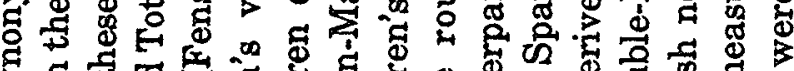

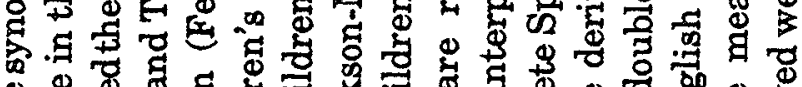

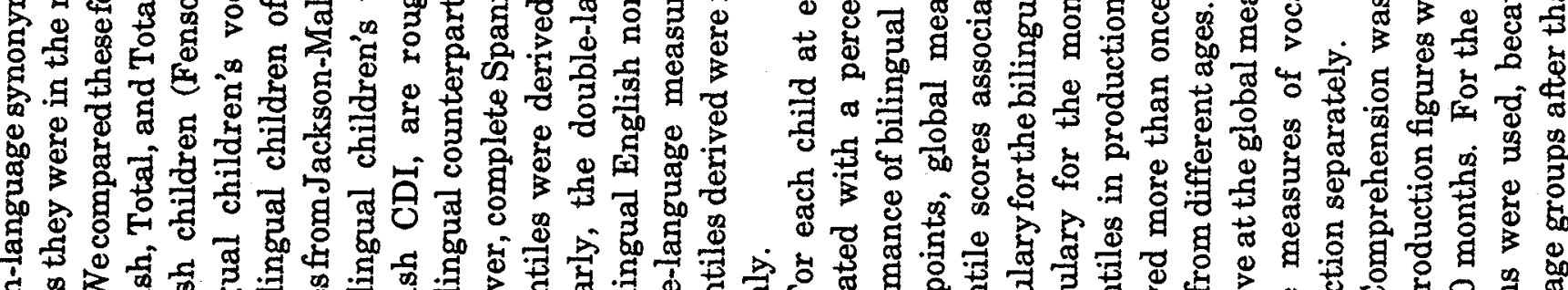

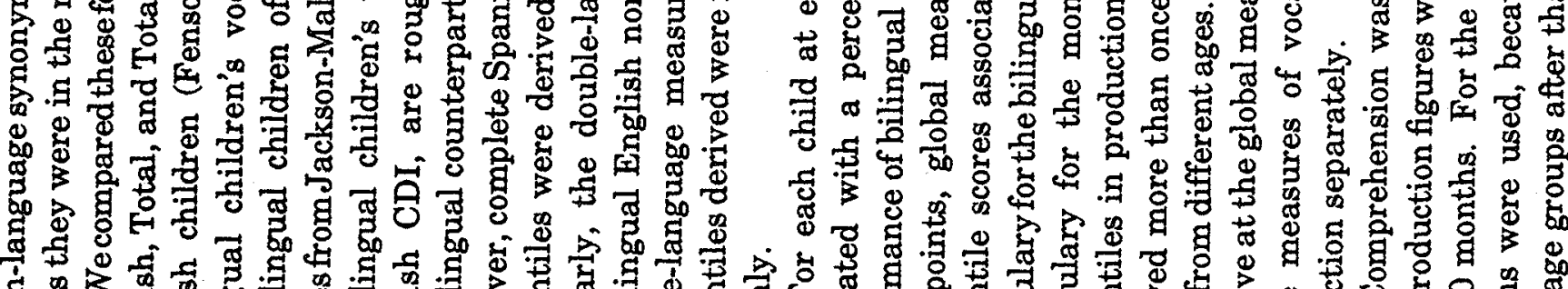

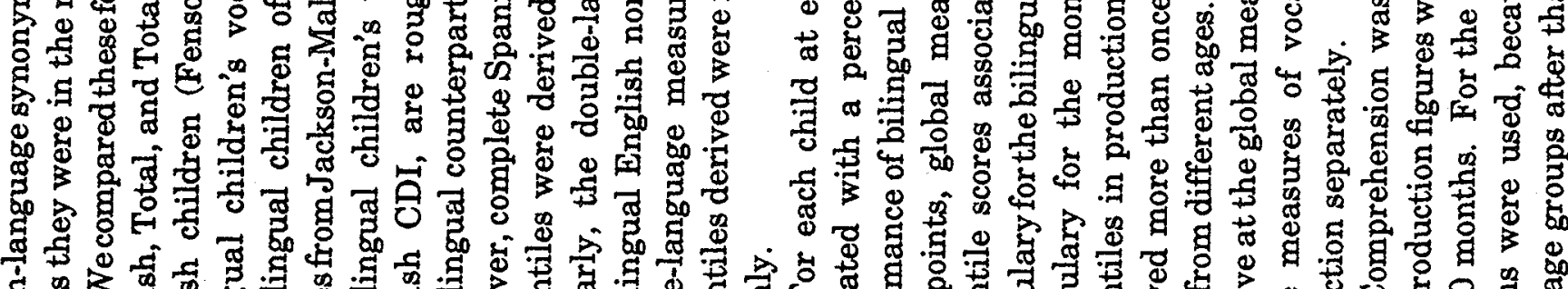

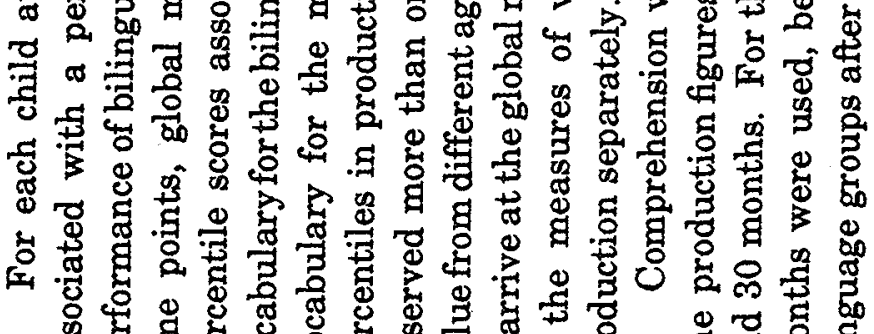

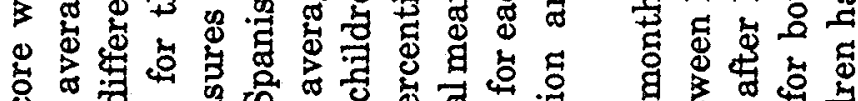
क

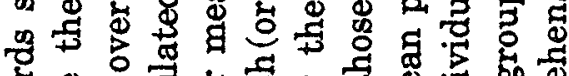
익

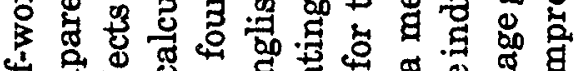

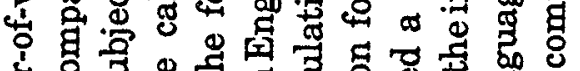

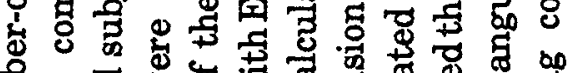

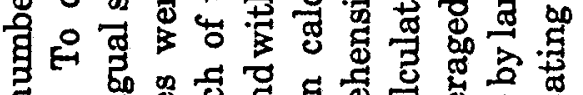
द

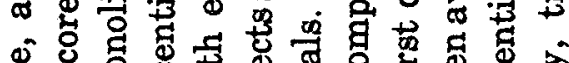

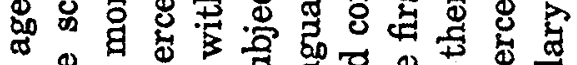
웜

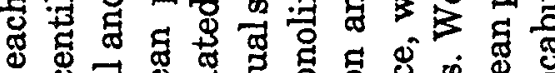

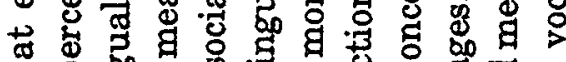

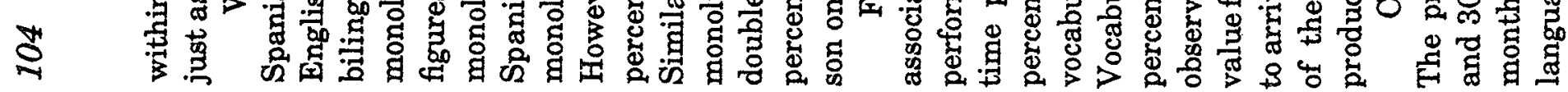



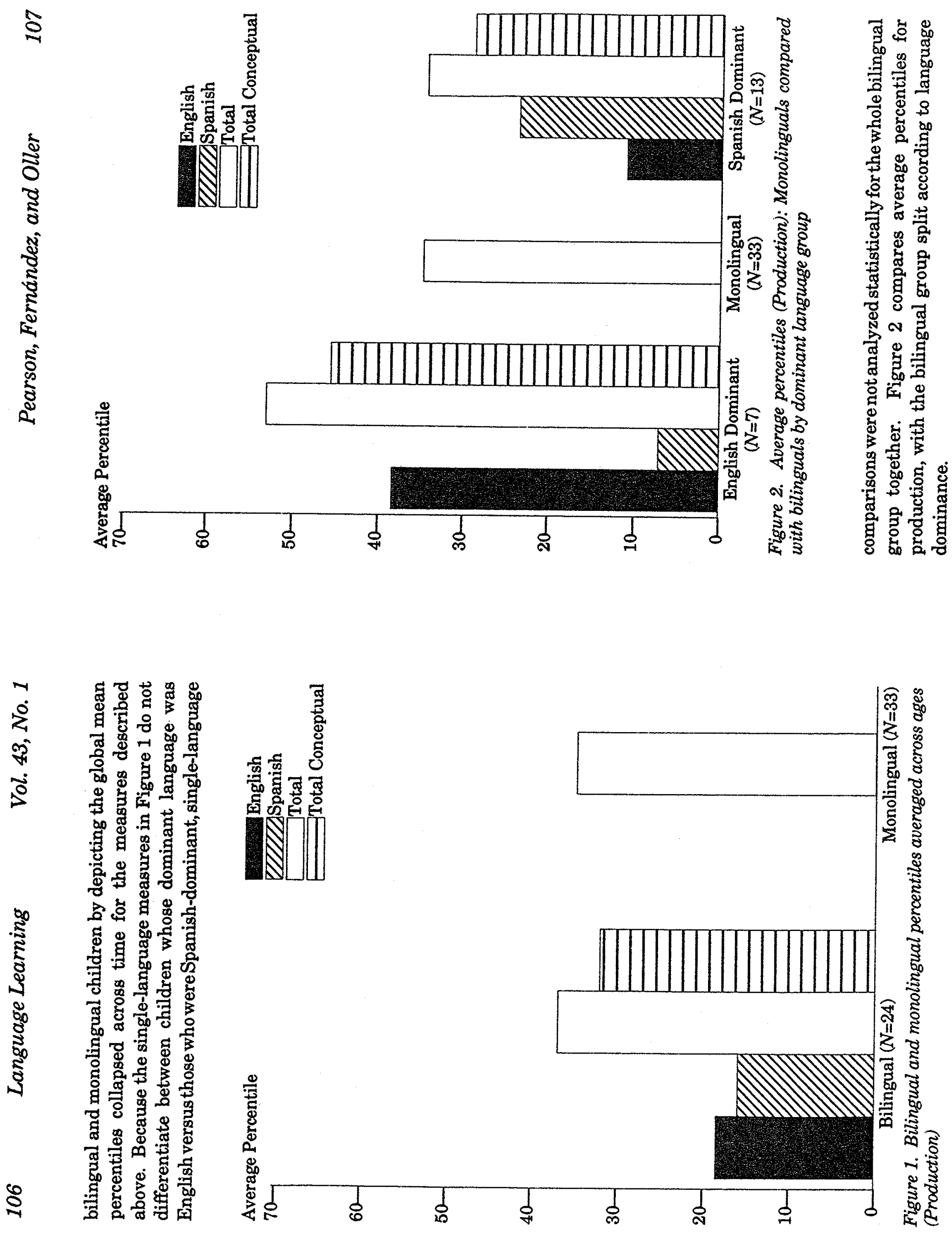

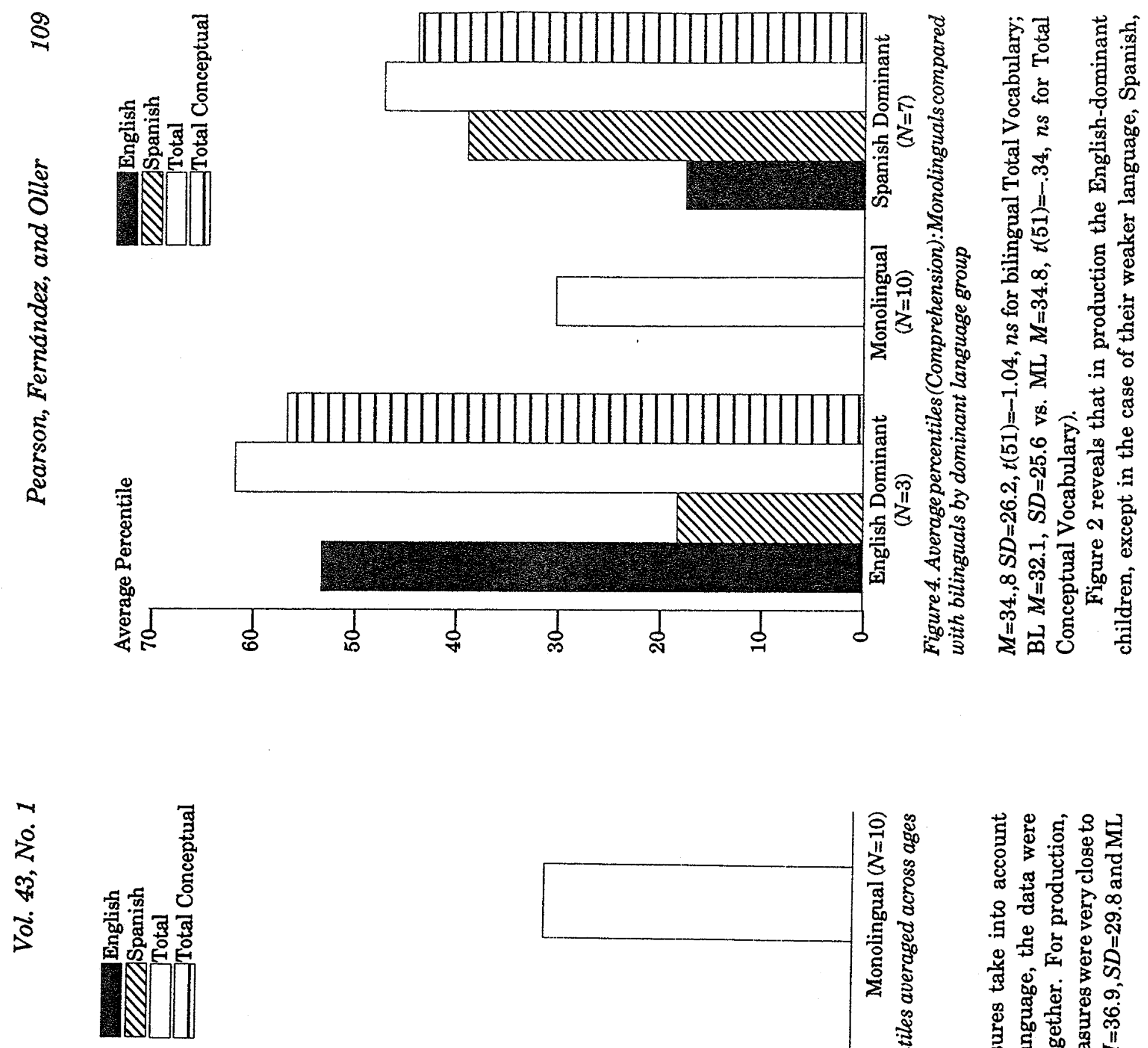

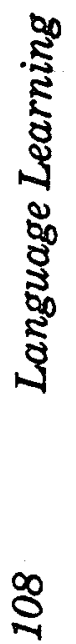
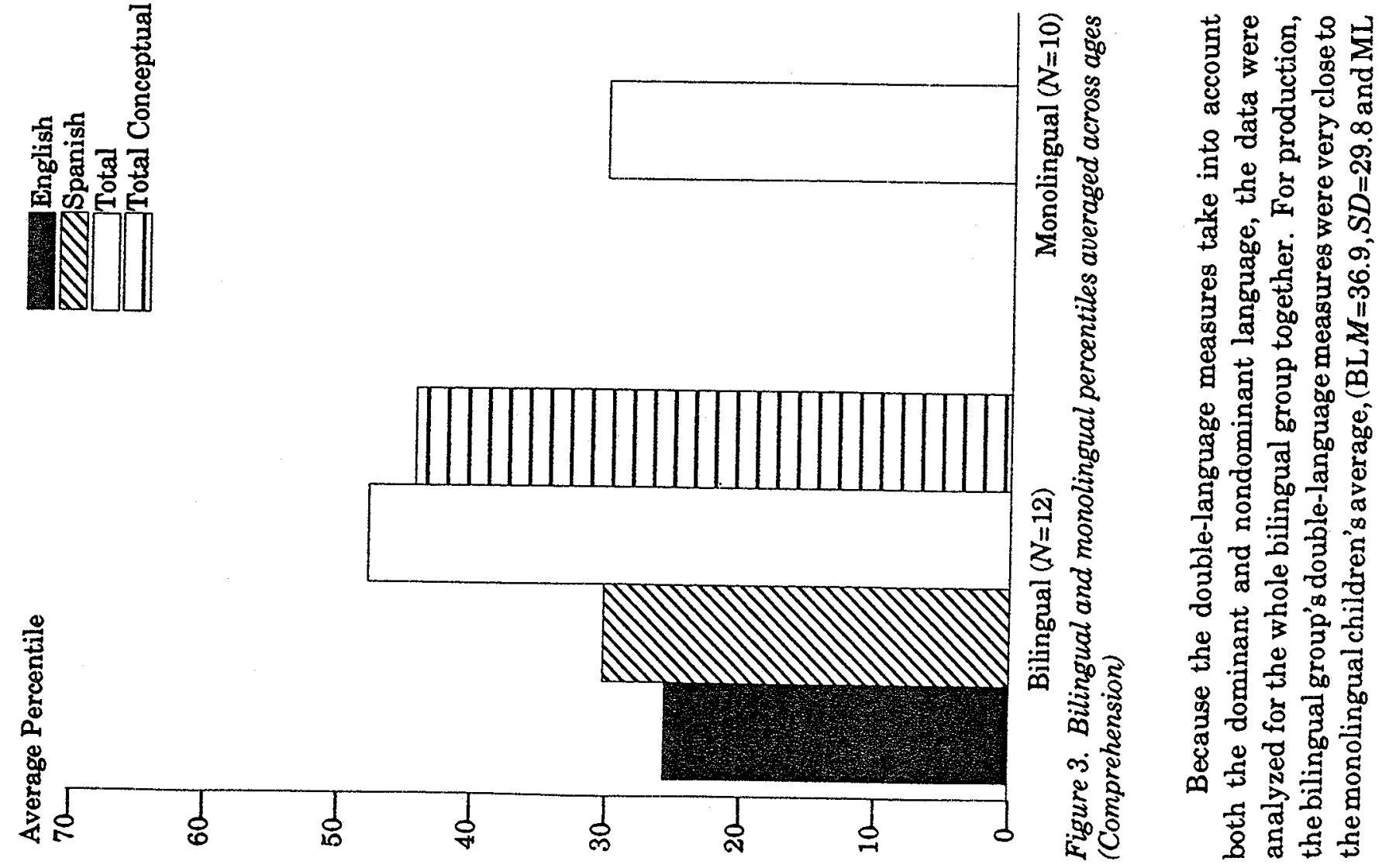


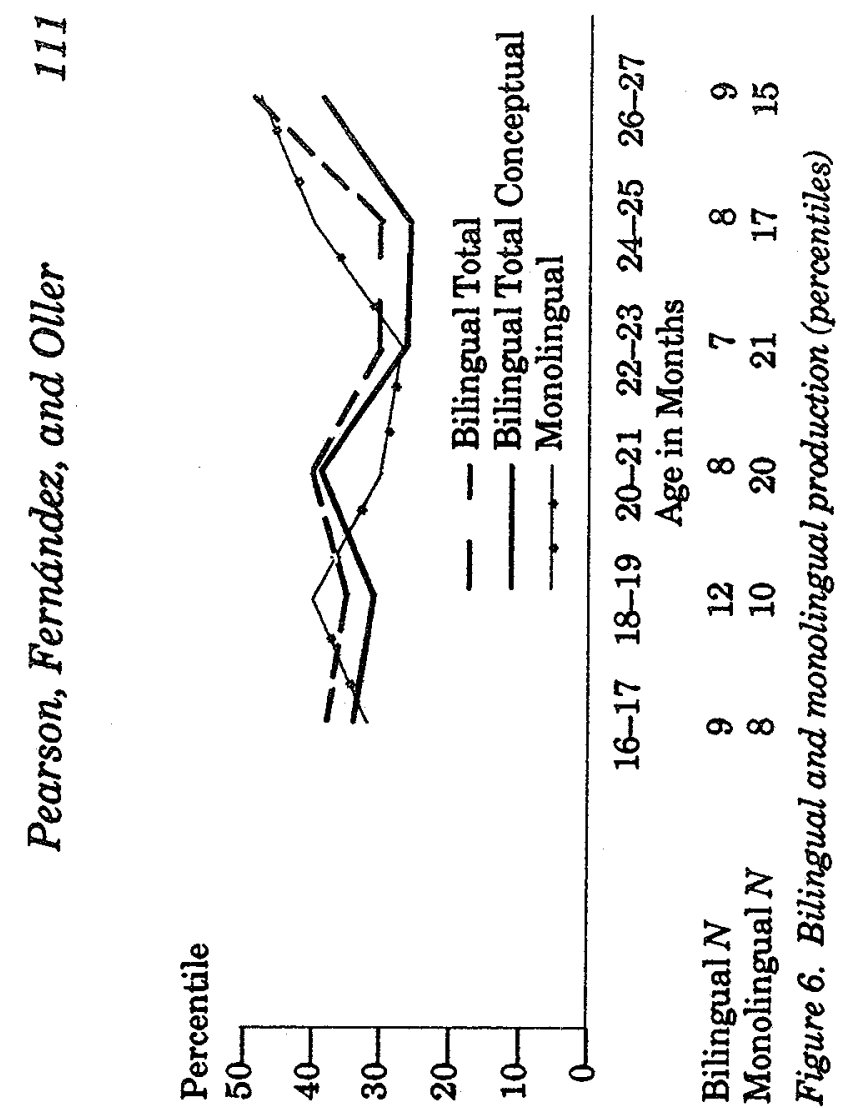

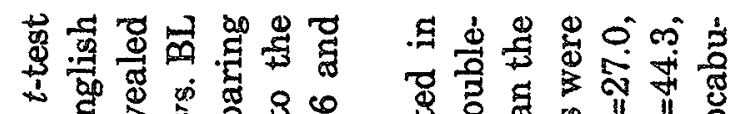
《国

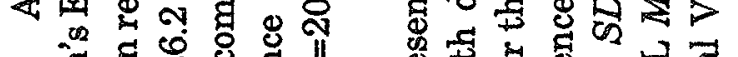

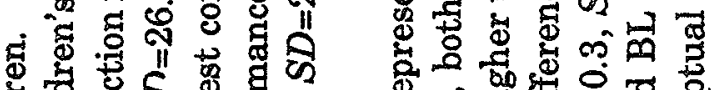

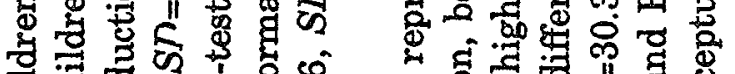

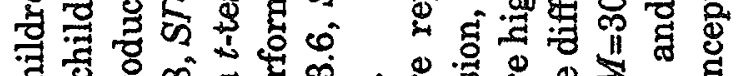
㝴 票范

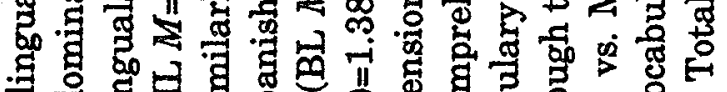

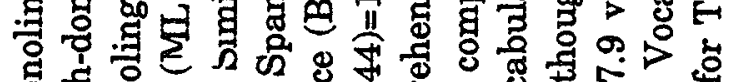

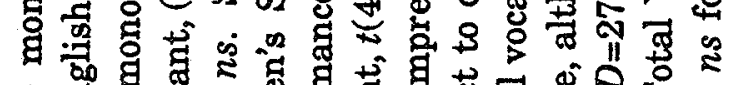

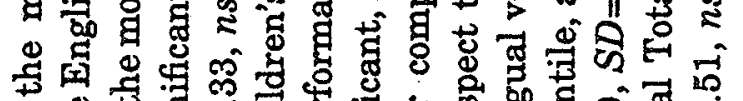

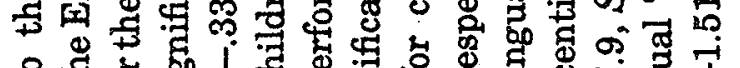

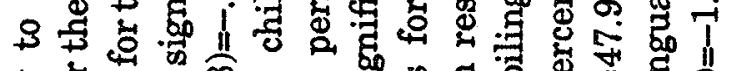

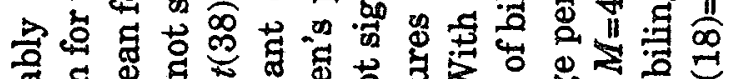

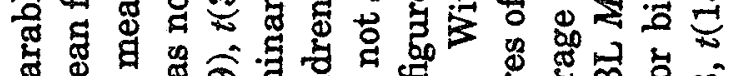

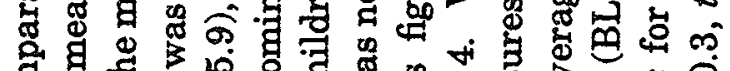

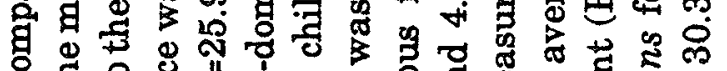

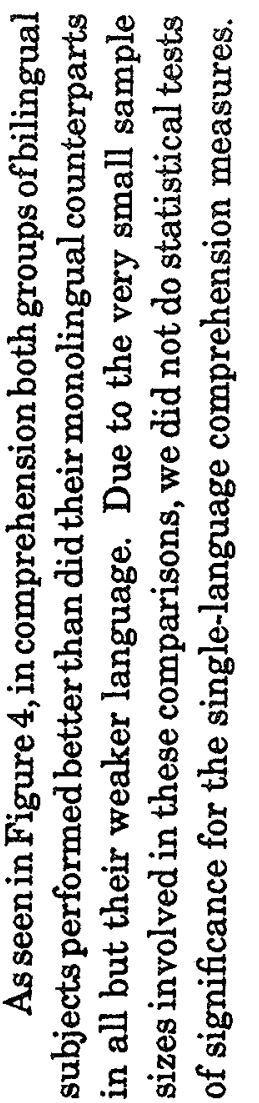

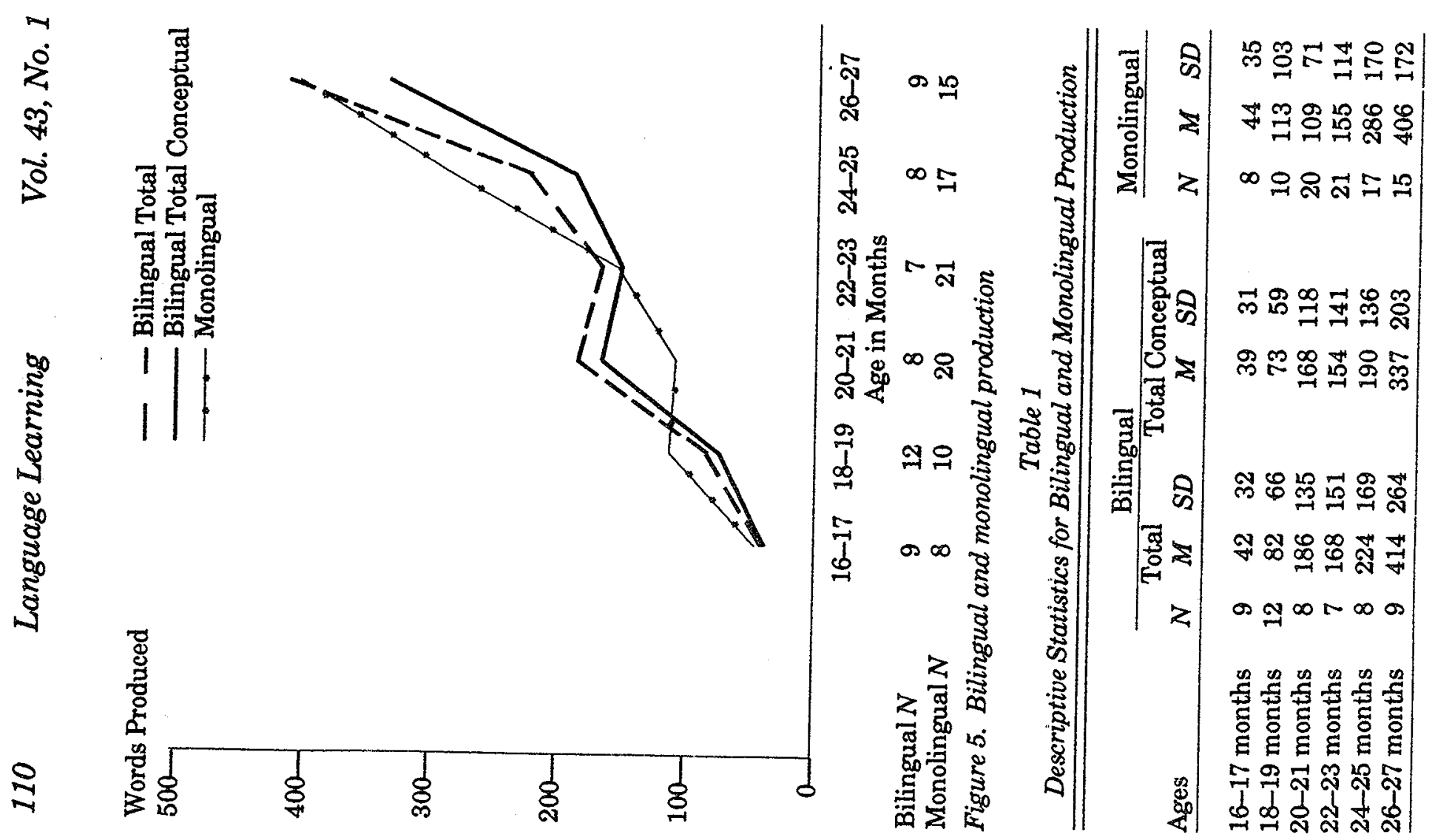



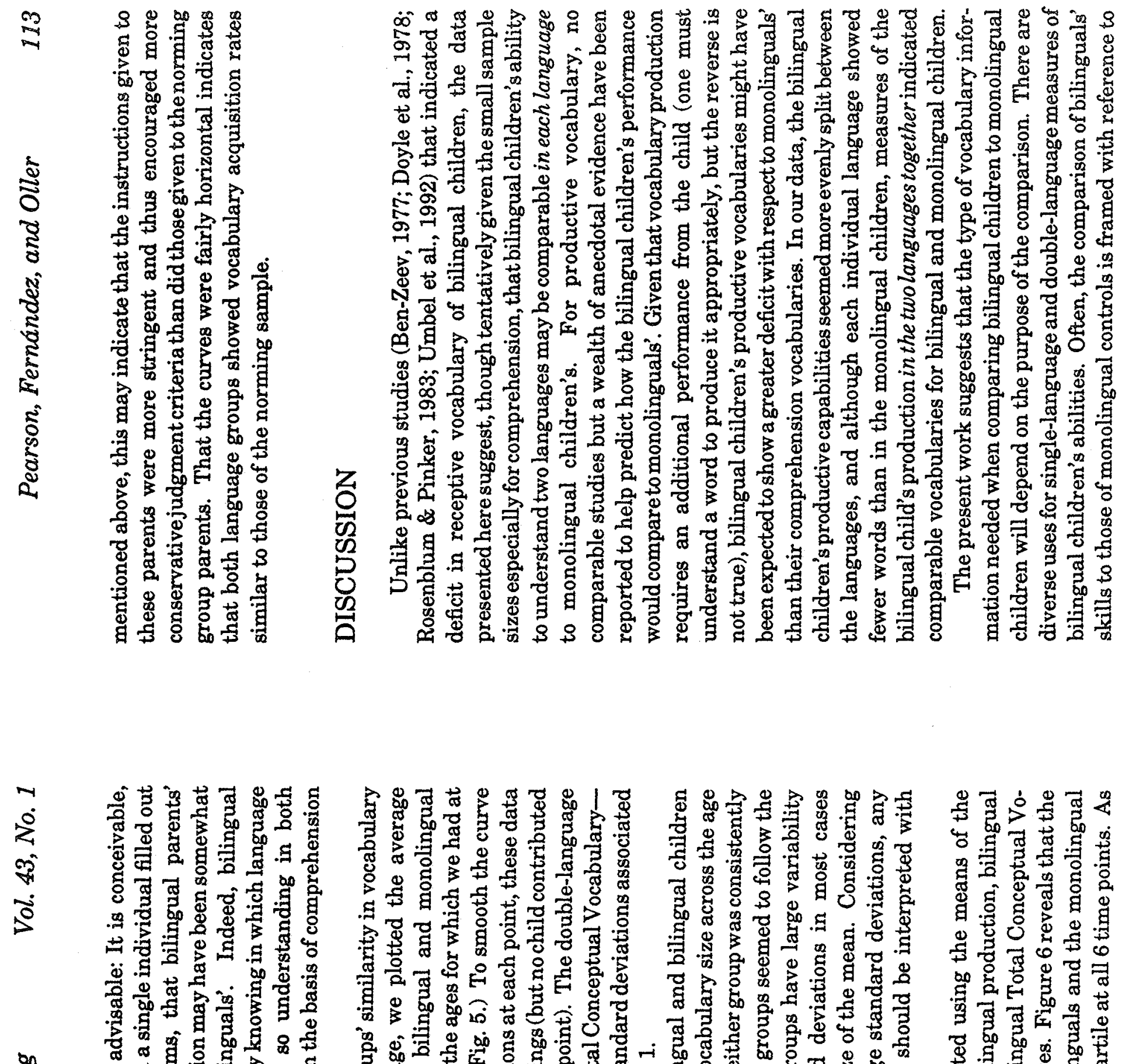

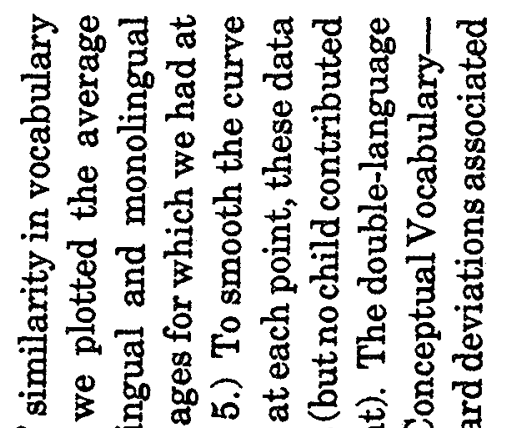

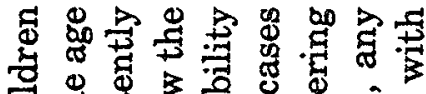

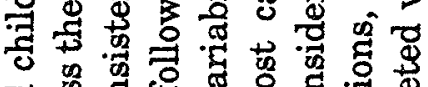

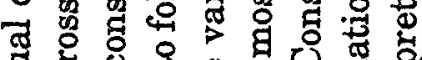
马ु .ే \%

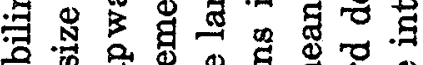

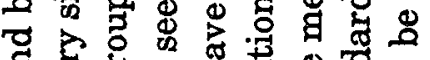
ส

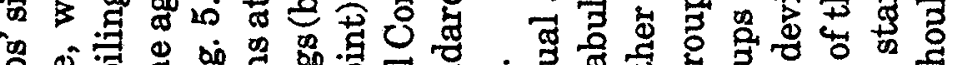

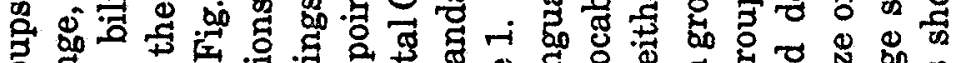

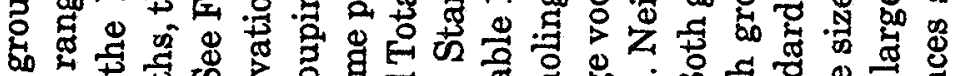

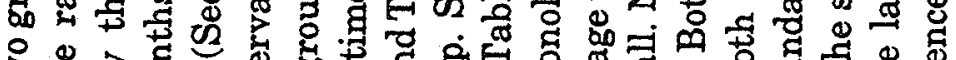

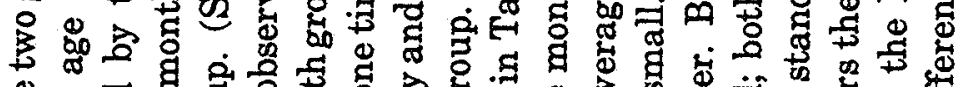

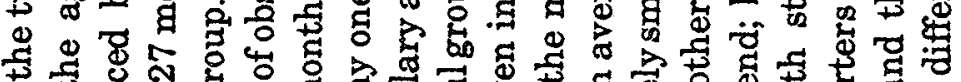

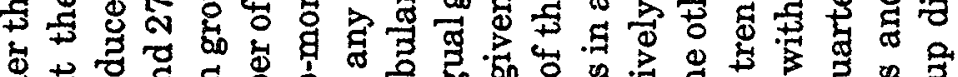

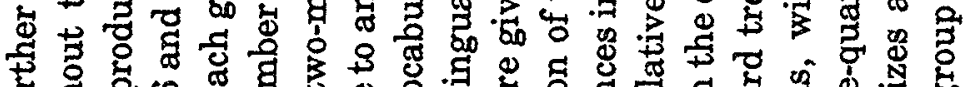

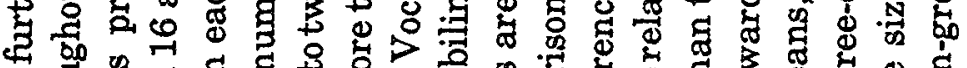

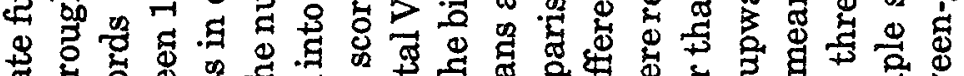

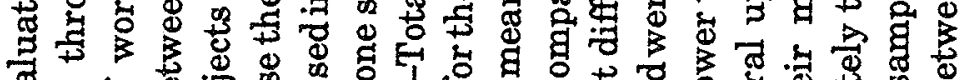

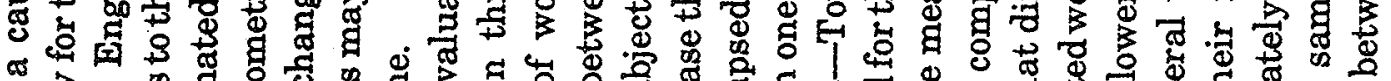

络

8

8

న్ర

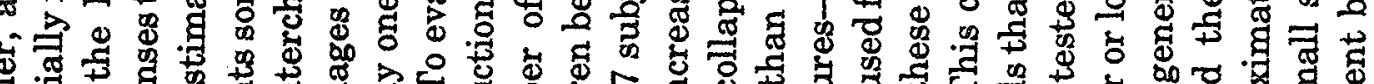

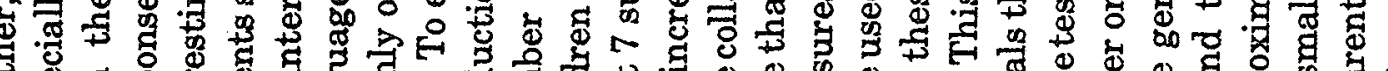

光

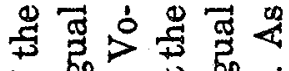
प.

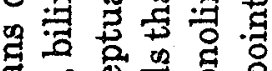
क : क्ष है घ. . 0 记跑 耳

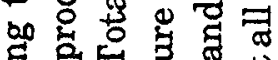

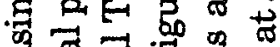

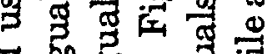
T

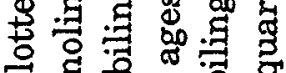

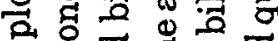

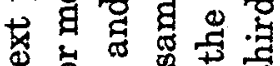
边

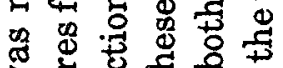
3 氜 동ㅎㅇ

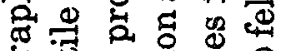

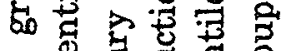

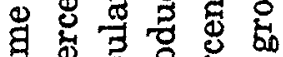
क

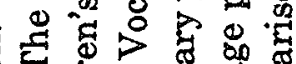

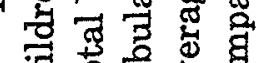

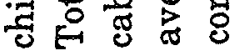




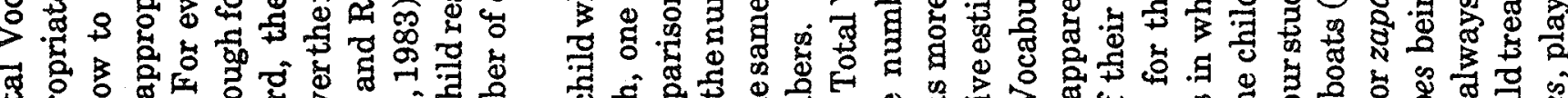
ॠ

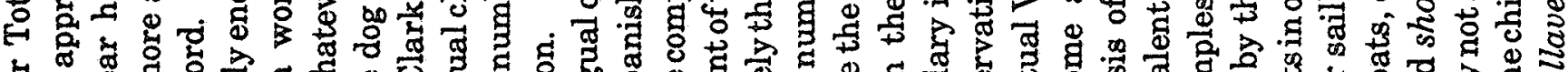

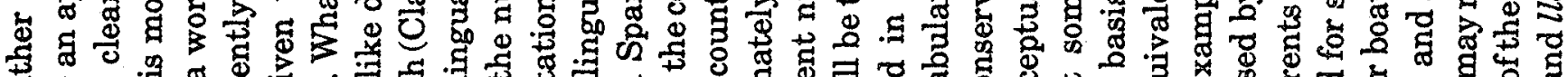

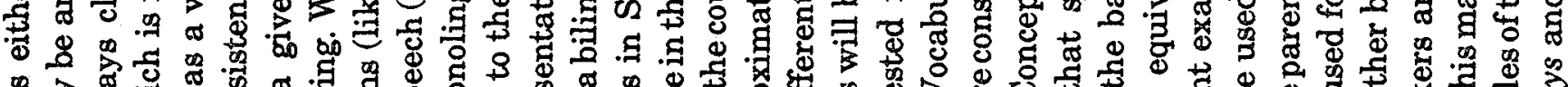

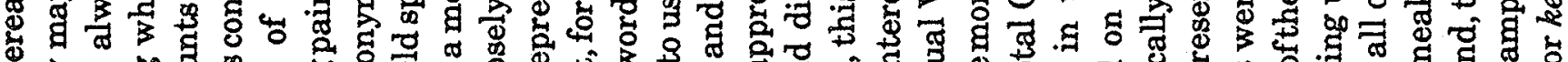

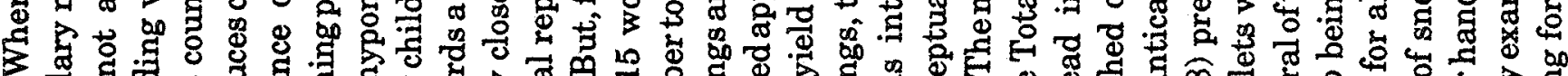

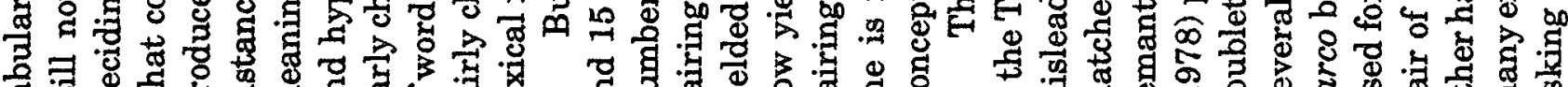

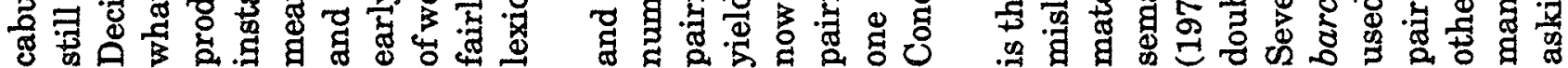

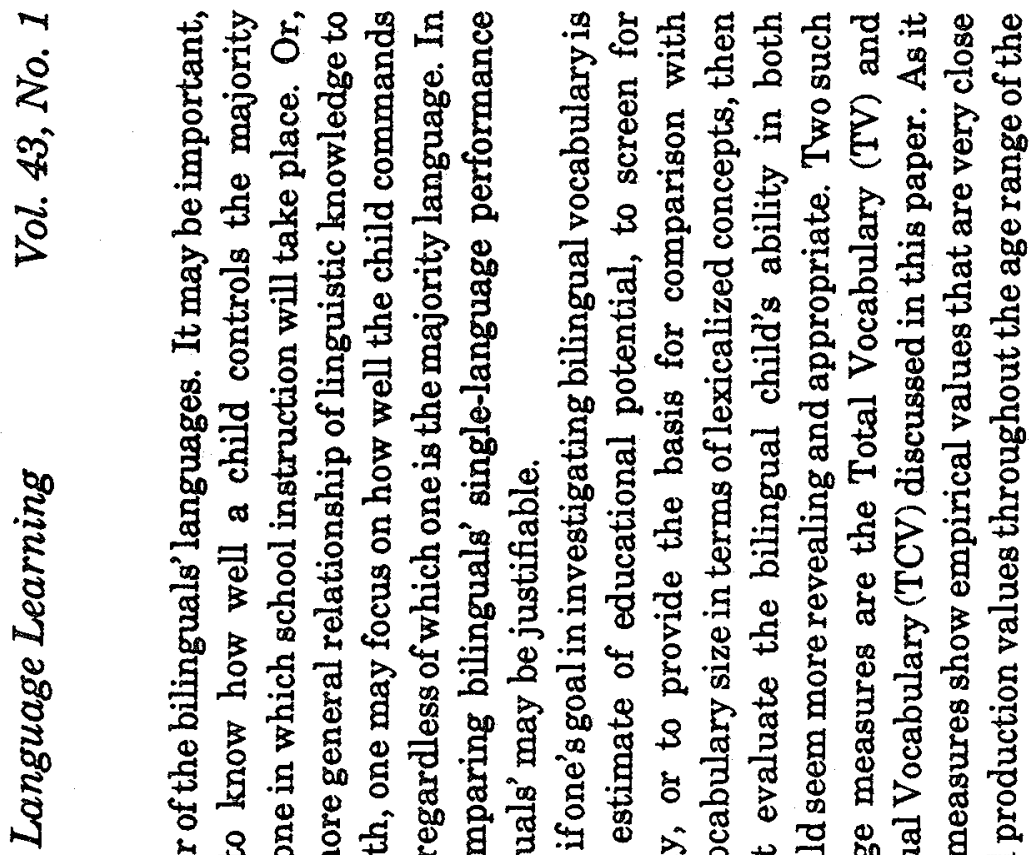

包望要

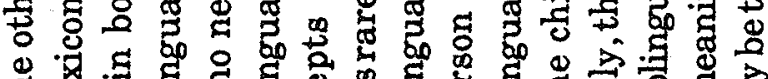

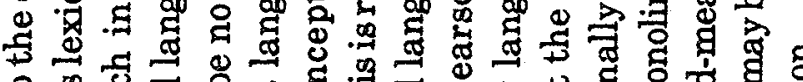

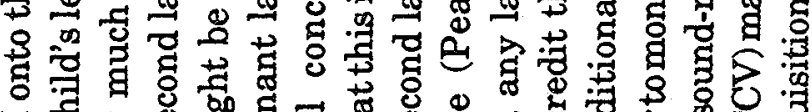

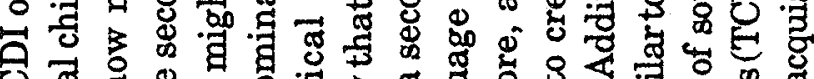

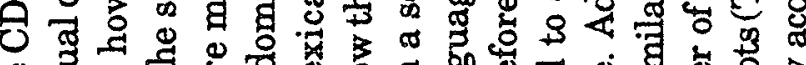
\&

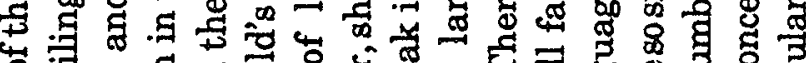

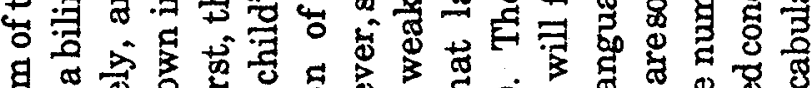

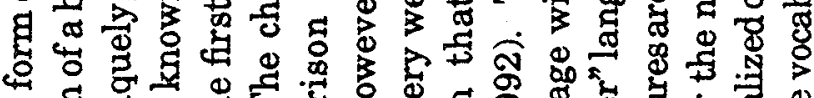

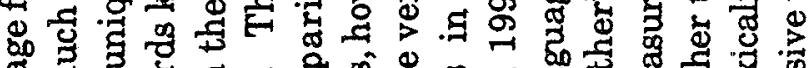

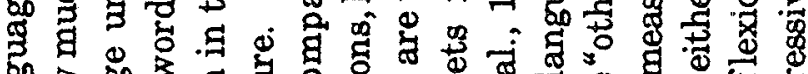

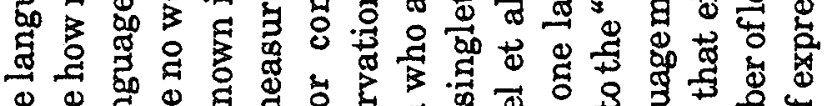

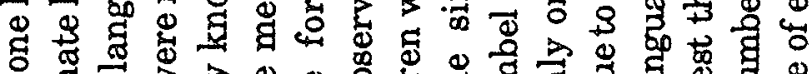

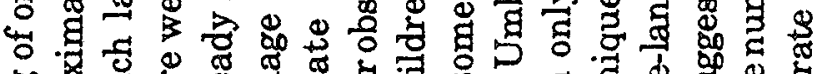

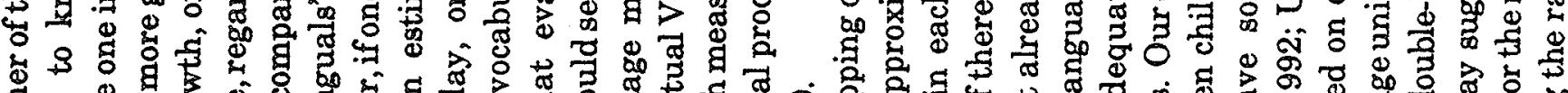

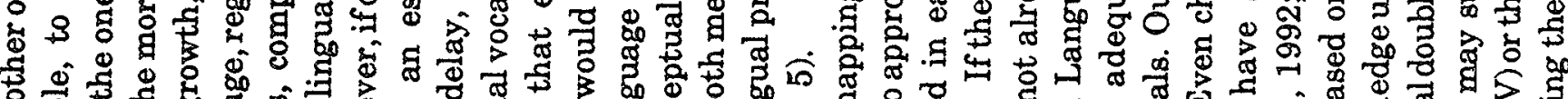
击

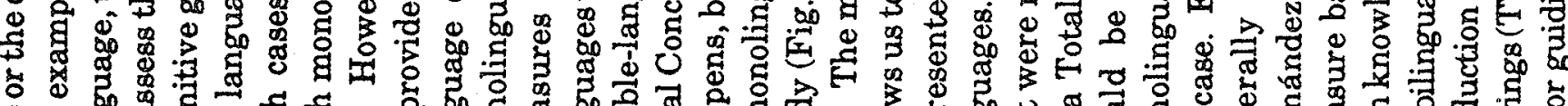

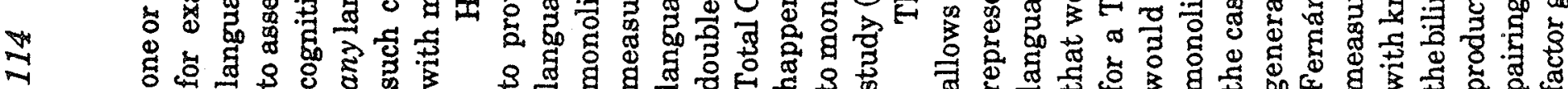


ปิ

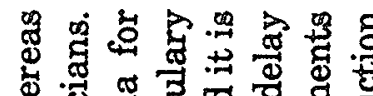

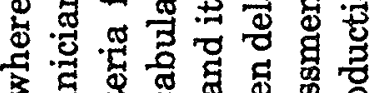

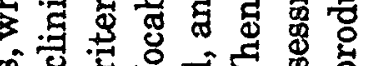

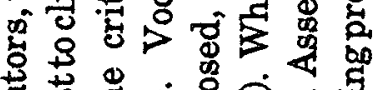

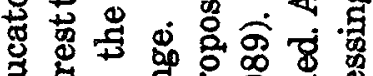

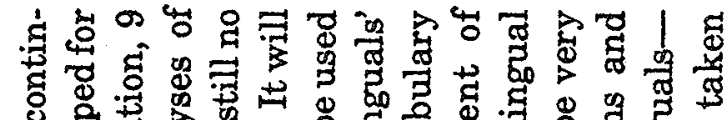

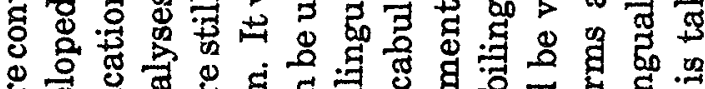

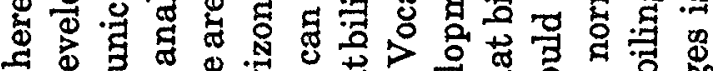

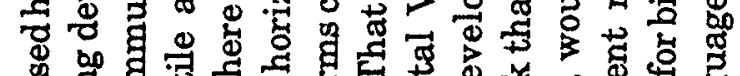

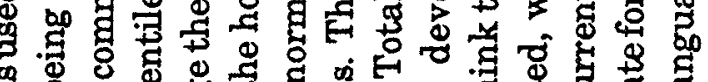

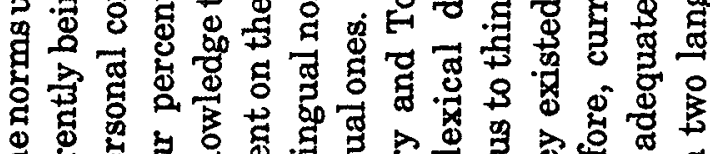

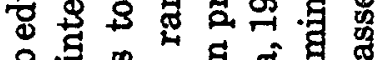
\$.

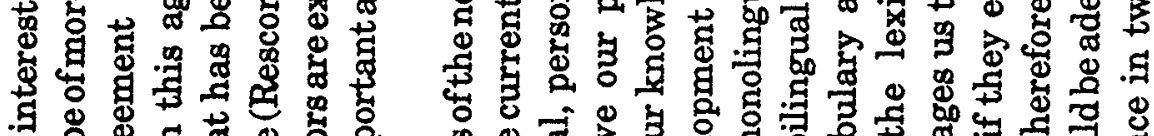
.5

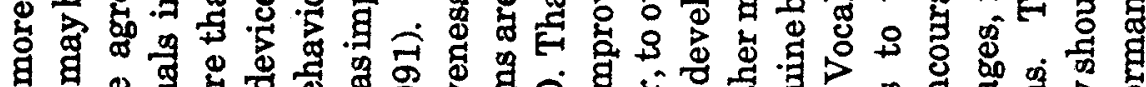

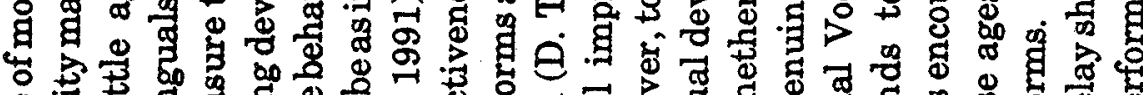

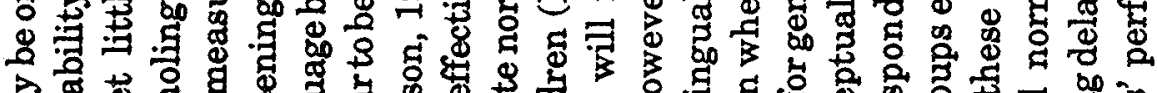

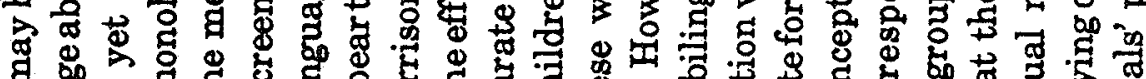

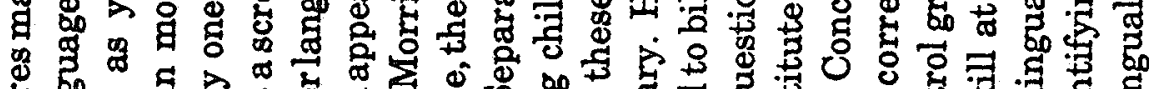

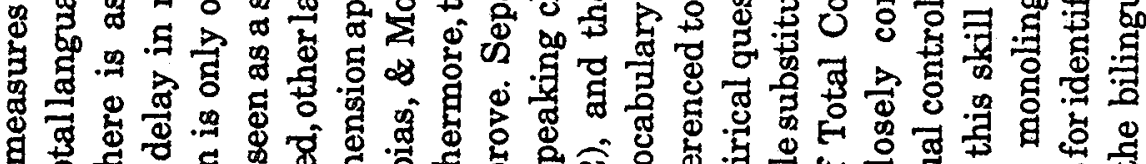
열 总 2. द्ञ

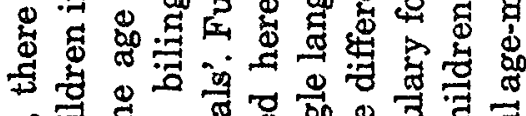
థ热志

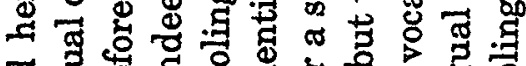

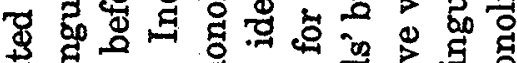

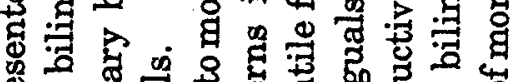
:

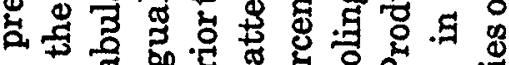

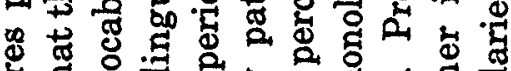

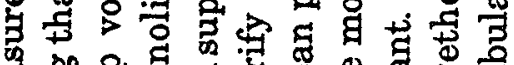

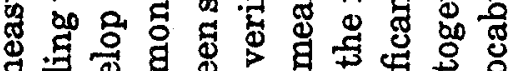

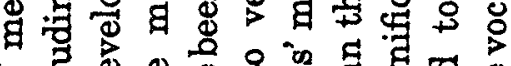
4 总总

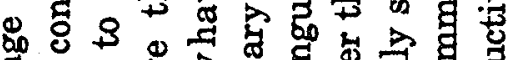

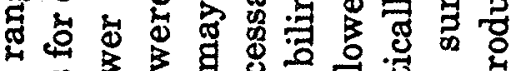

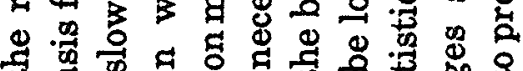
व

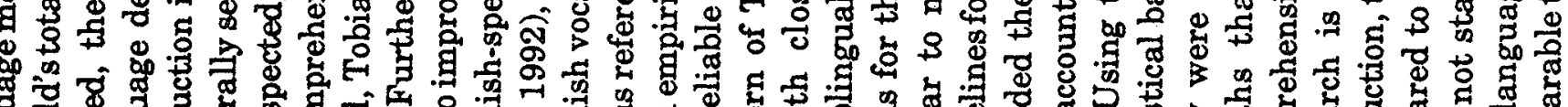

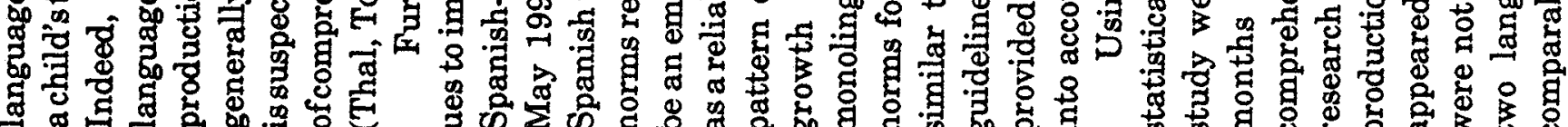

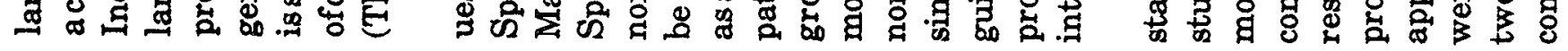

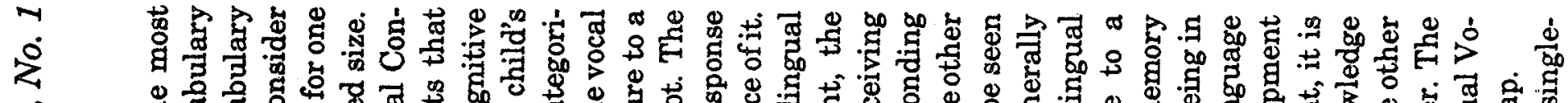

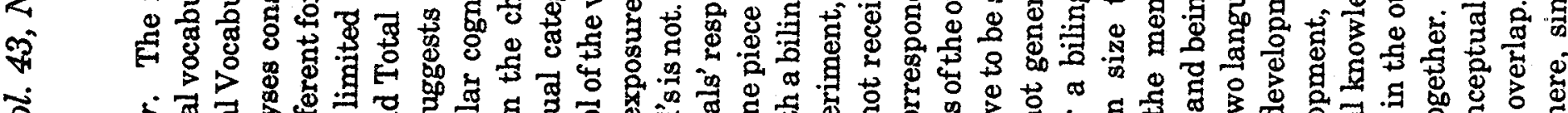
仓

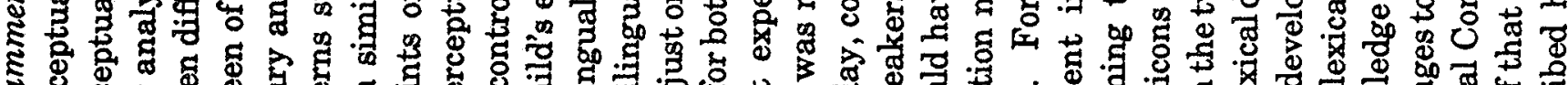
ర్

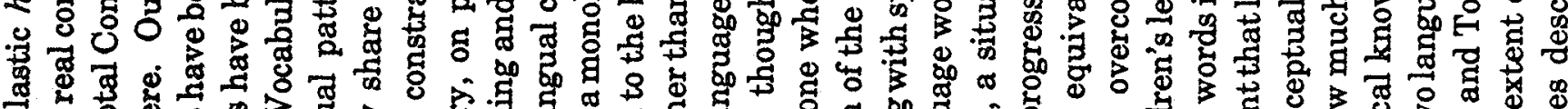

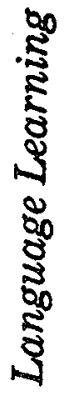

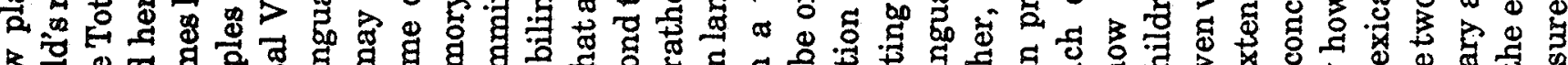

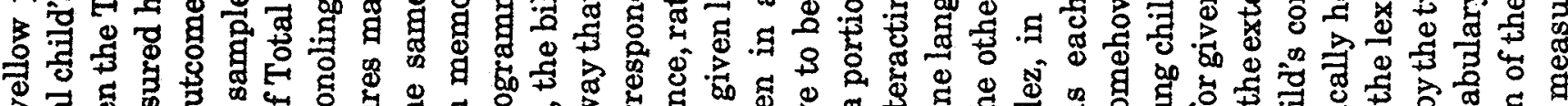
四

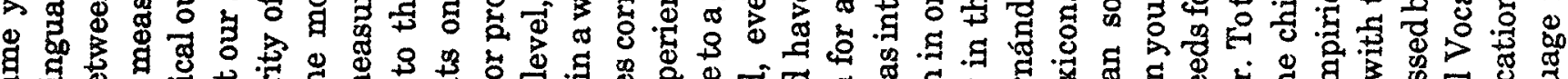

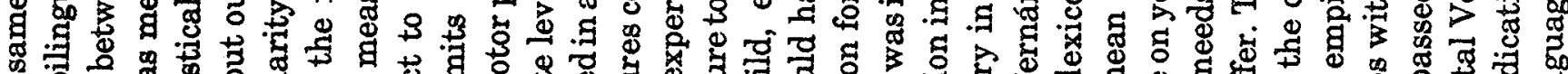

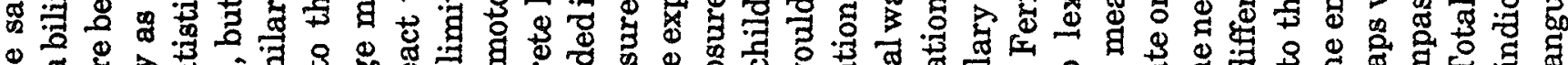

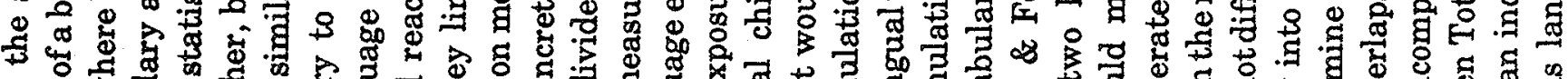

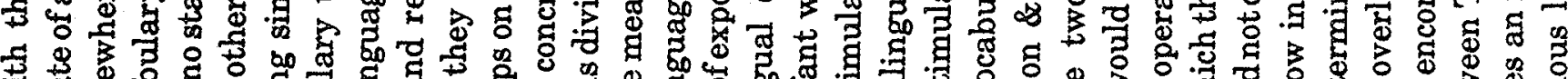

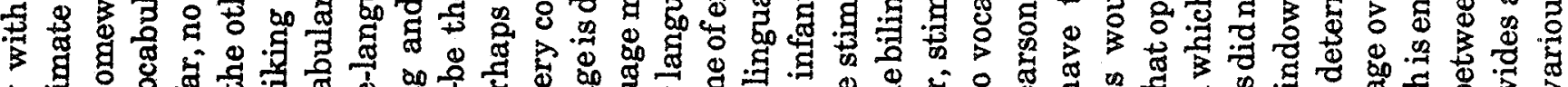

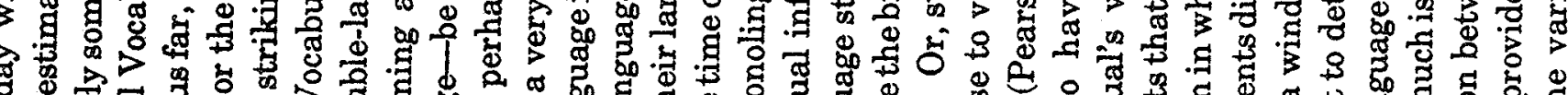
б

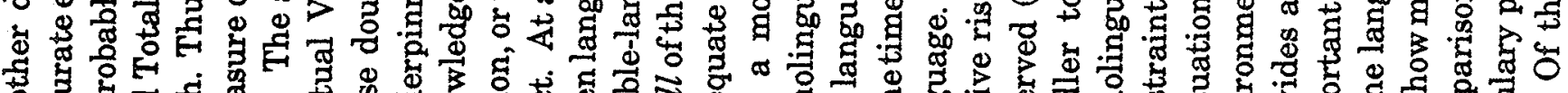

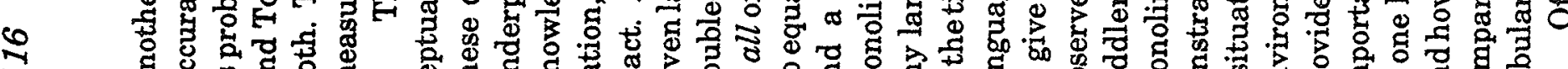

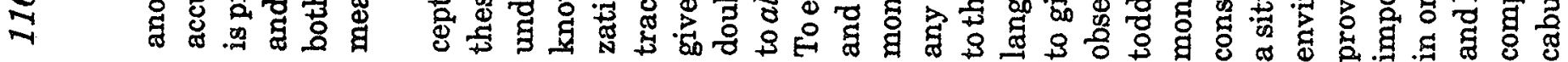




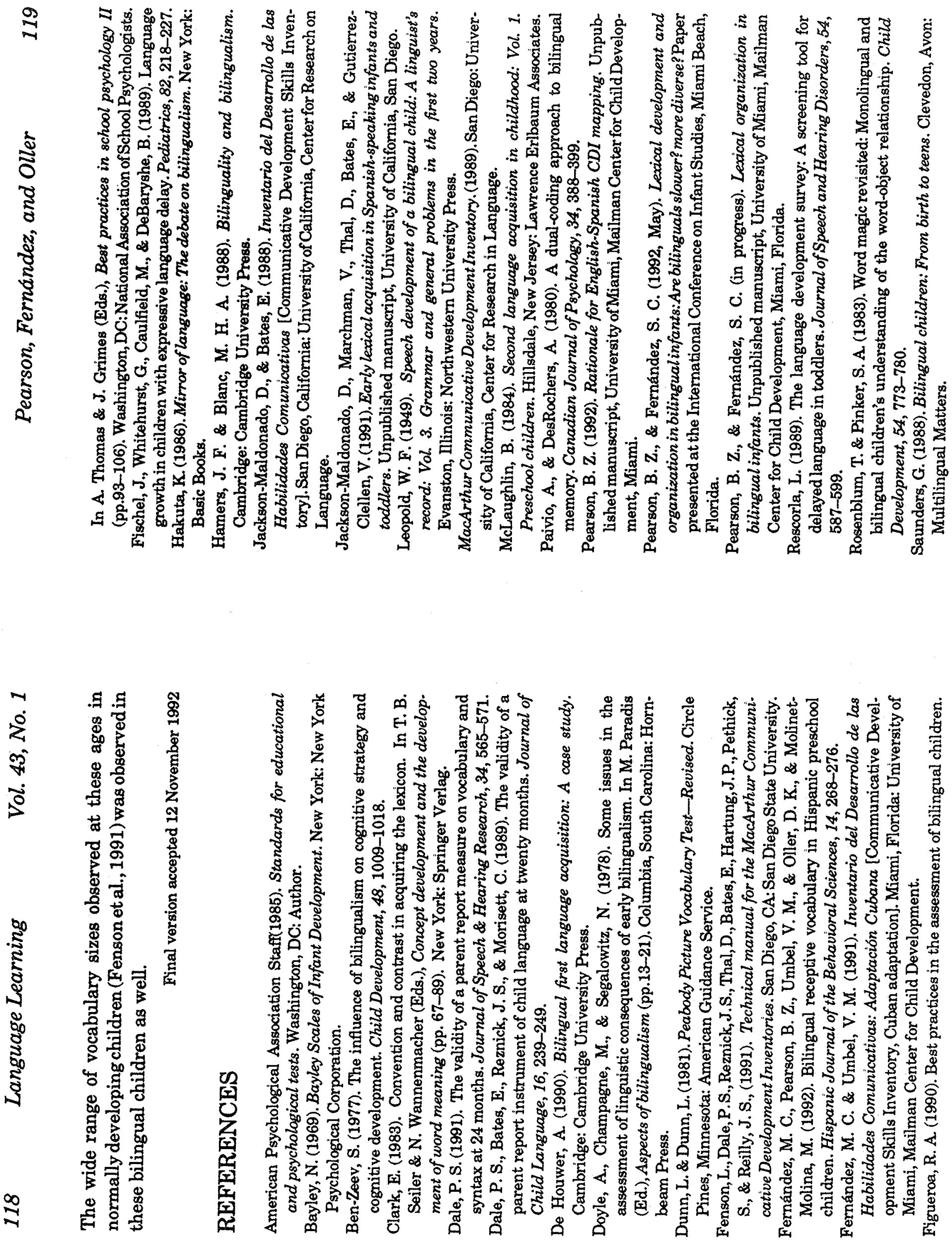




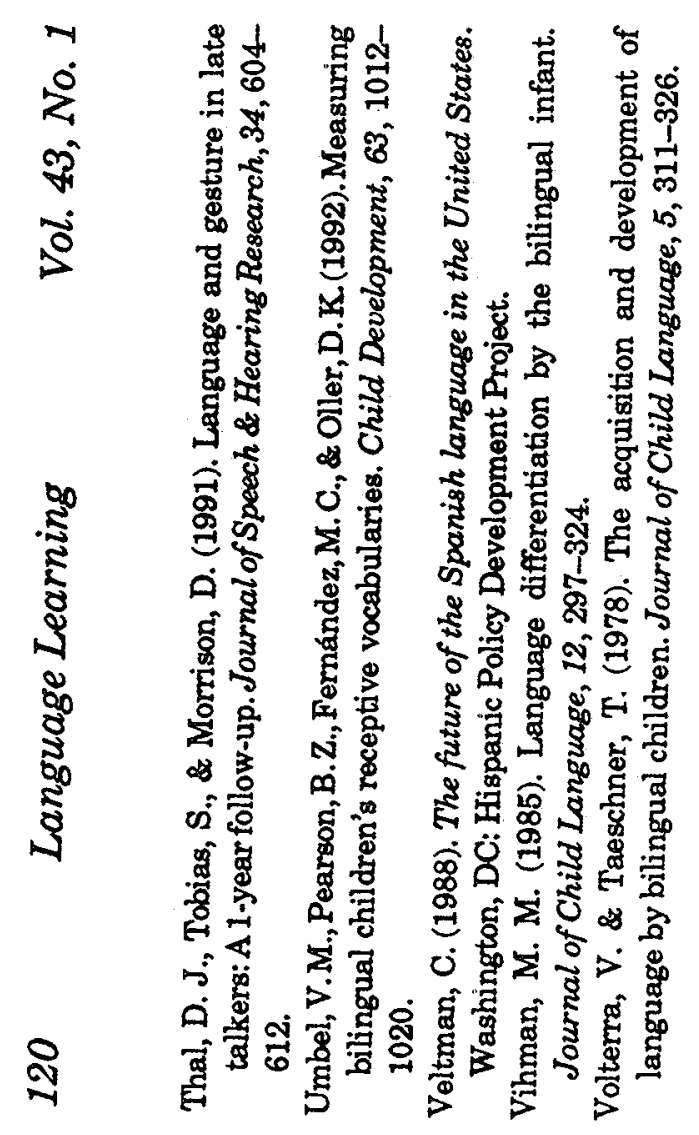

